\title{
“Nos edificó y admiró a todos aquellos que tuvimos la dicha de presenciar tan fausta Consagración". El Cardenal Eustaquio Ilundain y la dedicación de la Catedral en la Sevilla republicana de 1932
}

\author{
"He edified us and admired all those who had the \\ joy of witnessing such a wonderful Consecration." \\ Cardinal Eustaquio llundain and the dedication \\ of the Cathedral in Republican Seville in 1932
}

\author{
José Gámez Martín \\ Academia Andaluza de la Historia. Sevilla España \\ josegamezmartin@yahoo.es \\ ID ORCID 0000-0002-8007-1612
}

\begin{abstract}
Resumen: El Cardenal Ilundain consagró la catedral de Sevilla el 30 de octubre de 1932 en un difícil año para las relaciones entre la Iglesia y el Estado, motivado por el gobierno de la Segunda República. La ceremonia de dedicación no se había realizado desde el estreno del nuevo recinto catedralicio a primeros del siglo xVI. Se estudia el contexto y la rica liturgia, ofreciendo otros aspectos del pontificado del arzobispo de Sevilla como su nombramiento de cardenal en 1925.
\end{abstract}

Palabras Claves: Catedral de Sevilla, Relaciones Iglesia-Estado, Liturgia, Segunda República, Cardenal Ilundain

\begin{abstract}
Cardinal Ilundain consecrated the Cathedral of Seville on October 30, 1932 in a difficult year for relations between the church and the state, motivated by the government of the Second Republic. The dedication ceremony had not taken place since the opening of the new cathedral complex in the early 16th century. The context and the rich liturgy are studied, offering other aspects of the pontificate of the Archbishop of Seville such as his appointment as Cardinal in 1925.
\end{abstract}

Keywords: Cathedral of Seville, Church-State Relations, Liturgy, Second Republic, Cardinal Ilundain 


\section{EUSTAQUIO ILUNDAIN, CARDENAL DE LA IGLESIA. DATOS BIOGRÁFICOS}

En las vísperas de la Semana Santa de 1925 tiene lugar un acontecimiento especial en la vida del arzobispo de Sevilla, Eustaquio Ilundain Esteban. Exactamente la tarde del 30 de marzo, llegó mediante telégrafo desde Roma la noticia de que el papa Pío xI lo había elevado a la dignidad cardenalicia junto al arzobispo de Granada, Casanova, en un consistorio convocado únicamente para estos dos nombramientos de prelados españoles, lo que nos indica claramente la aceptación por el Vaticano del nuevo gobierno político del general Primo de Rivera, quien curiosamente tenía una gran amistad con el arzobispo granadino. ${ }^{1}$ La noticia fue muy bien recibida en Sevilla, ciudad en la que Ilundain ejercía como arzobispo desde el 15 de septiembre de 1921. ${ }^{2}$ En la reunión del cabildo municipal del 31 de marzo se decía:

El señor alcalde dirigió la palabra al Ayuntamiento para informarle de la promoción a la sagrada púrpura cardenalicia del Exmo. y Revmo. Arzobispo de esta Archidiócesis don Eustaquio Ilundain, sabio y virtuoso prelado, gloria de la Iglesia católica que ocupa dignísimamente la silla que honran los SantosYsidoro y Leandro, recayó por unanimidad con tan fausto acontecimiento el acuerdo de felicitar a Su Eminencia en nombre de la ciudad que tanto le admira y asistir corporativamente a las ceremonias que han de celebrarse para solemnizar la exaltación del nuevo cardenal. ${ }^{3}$

1 La llegada a Sevilla del telegrama pontificio con el nombramiento cardenalicio de su prelado está atestiguada en el Boletín Oficial del Arzobispado de Sevilla, núm. 1.042, 30 de marzo de 1925, 120-124. Treinta y cinco arzobispos de Sevilla han alcanzado la dignidad cardenalicia de manera alternativa desde Gómez Barroso en 1371 hasta Carlos Amigo en 2003. Es la segunda sede de España tras Toledo en tener entre sus prelados mayor número de cardenales.

2 El secretario particular del prelado y canónigo hispalense Laureano TOVAR González nos dejó una biografía del prelado que, pese a su tono hagiográfico, sigue siendo la principal fuente de referencia sobre el arzobispo navarro: Ensayo biográfico del Emmo. Señor Cardenal Ilundain y Esteban, Pamplona, 1942. José María JAVIERRE brinda un ajustado perfil de su personalidad y actividad pastoral en "La diócesis de Sevilla en el siglo XX", en Historia de las diócesis españolas. Sevilla, Huelva, Jerez, Cádiz y Ceuta, BAC, Madrid, 2002, 380-420. Un resumen más periodístico y ágil en Carlos Ros, Los arzobispos de Sevilla, Sevilla, Ediciones Anel, 1986, 278-282.

3 Archivo Municipal de Sevilla, Actas capitulares (1924-1926), F. 76. 
Hasta la reforma del nombramiento cardenalicio tras el Concilio Vaticano II por el papa Pablo vI, la entrega de las insignias catedralicias en España se ceñía a un ajustado protocolo: un encargado pontificio le traía al nuevo purpurado el solideo rojo; la birreta le era impuesta por el jefe del Estado, al igual que ocurría en Francia y, ya en Roma, el papa le otorgaba el capelo y el título de la Iglesia que le hacía unirse al clero romano.

Restablecido Ilundain de una gripe inoportuna la tarde delViernes Santo tiene que celebrar el cabildo catedralicio una reunión de urgencia en el coro ${ }^{4}$ para anunciar que al día siguiente llegaba el representante pontificio, acordándose por ello asistir corporativamente al acto en traje coral y que la Giralda repique durante tres días. ${ }^{5}$

El sábado de Gloria llegó el ablegado pontificio a las nueve y media desde la estación de trenes de Madrid a la sevillana de Plaza de Armas y se dirigió al palacio arzobispal, donde tuvo lugar en el salón del trono la entrega del solideo. El nuevo cardenal entró en su salón acompañado del cabildo catedral en pleno y asistido por el lectoral Santos y el deán Rivas, y tras él, el guardia noble, el conde Salineri, portando la nueva insignia cardenalicia. El acto comenzó con la lectura del nombramiento cardenalicio por parte del lectoral Santos, tras lo que el guardia noble subió al trono y entregó el solideo a Ilundain, que se quita el de arzobispo y se coloca el nuevo de cardenal entre aplausos de la concurrencia. Don Eustaquio, emocionado, ofrece un discurso de agradecimiento en el que muestra su adhesión al papa, respondiéndole en forma de felicitación el deán catedralicio. En el acto, al que asisten también los obispos de Córdoba y Cádiz, están presentes las principales autoridades de la ciudad: el cabildo municipal en pleno, el gobernador militar, exministros, la diputación civil y señores condecorados, siendo llamativo que no estuviera presente ningún representante de las cofradías debido sin duda al intento de Ilundain de erradicar los excesos de los desfiles penitenciales. ${ }^{6}$

4 Estas reuniones capitulares canonicales en el coro se realizaban por motivo de algún asunto urgente y eran llamadas del Águila por celebrase a los pies del símbolo joánico en bronce que se encuentra en la zona de liturgia coral del Cabildo Catedral.

5 Cf.Archivo Catedral de Sevilla (en adelante ACS): Secc. I, Secretaría: Autos Capitulares: Libro 232 (1921-1925), F.200. Por economía de espacio en adelante me referiré a las actas catedralicias como Autos sin mencionar la sección ni el enunciado.

6 Cf. Boletín Oficial del Arzobispado de Sevilla (desde ahora BOAS) núm. 1.043, 15 de abril de 1925, 137-143 y Hemeroteca Municipal de Sevilla (desde ahora HMS): El Liberal, Sevilla, 13 de abril de 1925, 2, y Tovar, Ensayo, 308-310. 
La tarde del día 13 el cardenal sale hacia Madrid, donde el 16 Alfonso XIII, en compañía de su familia y de toda la corte, le hace entrega de la birreta junto al también nuevo cardenal arzobispo de Granada. Los nuevos purpurados llegaron a palacio en coche de caballos, cada uno con su representante pontificio, y la familia real se dirigió a la capilla real en procesión de gala acompañada de los acordes de la Marcha Pontificia, lo reyes ocuparon el sitial real y, tras la lectura de las bulas pontificias de nombramiento, el ablegado ofreció al monarca en bandeja de plata las birretas y éste, ataviado con uniforme de gala y exornado con profusas condecoraciones presididas por el Toisón de Oro, las toma en sus manos. Ilundain y Casanova se acercan por separado al rey y las reciben tras realizar tres reverencias al mismo que tras imponerles el distintivo en la cabeza, da un abrazo a cada nuevo cardenal. El ablegado pontificio Santos pronuncia un discurso en latín ponderando las virtudes de los nuevos cardenales, respondiendo a estas palabras y en nombre de los dos Ilundain, que da la bendición solemne, pasando ambos después a la sacristía para revestirse con sus nuevos ornamentos y asistiendo a continuación a una misa oficiada por tres capellanes reales. Entre la nutrida presencia de invitados merece destacarse la de los cardenales Benlloch y Vida, arzobispos de Valencia y Tarragona, además de varias representaciones de Sevilla, Granada y Pamplona. El monarca agasajó a sus invitados con un almuerzo y, hay que hacer constar que vino expresamente para participar en la ceremonia el presidente del gobierno, que comenzó ya a entablar amistad con Ilundain, lo que hizo que dos años después lo propusiera como arzobispo de Toledo, nombramiento que al parecer no se materializó al entender la Santa Sede que el cardenal sevillano aún no tenía la experiencia necesaria para la enrevesada política de la sede primada de las Españas y también, lo que es más probable, por propia renuncia del interesado, aduciendo el escaso tiempo que llevaba en Sevilla y su propósito de cumplir el trabajo trazado a los pies de la Giralda. ${ }^{7}$

7 Cf. BOAS, núm. 1.043, 1 de mayo de 1925, 149-152. La teoría de la no designación de Ilundain para la Sede de Toledo la presenta con buen criterio, y basándose en la biografía de Tovar, JAVIERRE, Historia de las diócesis, 389. 
La noche del día 17, el nuncio ofreció un banquete a los nuevos cardenales y a la familia real, siendo ésta la primera vez que "un rey de España es huésped de la morada del pontificio representante". ${ }^{8}$

Ilundain parte hacia Sevilla el domingo 19, ya en la ciudad es recibido con todos los honores y con las autoridades en pleno en el andén de la Plaza de Armas, organizándose una procesión triunfal por calles céntricas sevillanas hasta la catedral donde, entrando por la Puerta de los Príncipes, se cantó un Te Deum en el altar mayor, celebrándose una misa rezada en un altar portátil colocado en el presbiterio bajo para que los fieles cumplieran con el precepto dominical. Don Eustaquio rezó ante laVirgen de la Antigua y se dirigió a palacio, donde se celebró la ceremonia oficial de homenaje.

A pesar de algunos problemas con las cofradías con el fin de retomarlas a los caminos de la seriedad, tanto en el andén de la estación como en el palacio arzobispal, homenajearon al cardenal "los hermanos mayores del Gran Poder, Esperanza de Triana, Jesús ante Anás y otras hermandades". ${ }^{\prime}$.

El nuevo cardenal recibió otra serie de homenajes, entre ellos el celebrado en su tierra natal Pamplona, siendo el más conocido de los celebrados en Sevilla, el de los Luises el 9 de junio y organizado por la Asociación de Caballeros de San Fernando y María Inmaculada, actual germen de la Real Hermandad de Caballeros de San Fernando. ${ }^{10}$

La entrega del capelo se demoró hasta el mes de diciembre, habiéndosele entregado por parte de Pío xi el 19 de ese mes, tal como fue testificado por el propio Ilundain mediante telegrama dirigido al cabildo catedral. ${ }^{11}$ En los días navideños tomó posesión así mismo de su título presbiteral romano de la Iglesia de San Lorenzo In Panisperna, instituido por el papa León x (1513-1521) en 1517 al aumentar en ese año la presencia numérica del colegio cardenalicio y habiéndolo

8 Blanco y Negro. Madrid, Prensa Española, 22 de abril de 1925. Recoge la imposición real con algunas fotografías del acto.

9 BOAS, núm. 1.043, 1 de mayo de 1925, 149-152 y Tovar, Ensayo biográfico, 310-312.

10 Cf. JaVIerRe, Historia de las diócesis, 389.

11 Cf. ACS: Autos, Libro 232 (1921-1925), F. 236 vto. Su texto en BOAS, núm. 1.057, 15 de enero de 1926, 161-166. 
ostentado solo un español antes que don Eustaquio: Buenaventura Fernández de Córdoba y Spínola de la Cerda (1724-1777) ${ }^{12}$

Volvió a Sevilla el 13 de enero, recibiéndolo la ciudad en idéntica ceremonia a la celebrada a la vuelta de Madrid tras recibir la birreta de manos de Alfonso.

Ilundain sabe que ha alcanzado la máxima distinción nobiliaria concedida por el Santo Padre y además piensa que el único ascenso que le queda en cuanto a importancia de una sede es Toledo a la que incluso en el futuro renunciará. Don Eustaquio se acordará de la mayor parte de su vida en esas jornadas en las que sabe que su gran responsabilidad como príncipe de la Iglesia será formar parte con su voto en la elección de un papa.

Había nacido de familia carlista tradicional en la política y en el saber en la Pamplona de 1862, donde la monarquía isabelina vivía ya en un lamentable letargo que le conduciría a la llegada de la república siete años después. Sus padres se llaman Juan Cruz Ilundain y Rafaela Estebe, ambos con gran relación y amor a la urbe navarra que siempre soñaría con la grandeza del antiguo reino pero que vivía en los años medios del ochocientos las carencias de una España inestable en lo temporal y vertiginosa en lo político; una Pamplona que no avanzaba con los tiempos y que no vería en su urbanismo un necesario ensanche entre la ciudad y la ciudadela hasta 1888. Desde sus primeros años, Esteban muestra vocación religiosa por lo que recibiría lecciones de latín de un lingüista conocido ya que tanto el seminario como todos los centros de estudios se encontraban cerrados debido a la irrupción de la tercera guerra carlista entre los partidarios de Carlos, duque de Madrid por parte tradicional y el reinado de Amadeo I, la primera república y su culminación con la instauración en el trono de Alfonso XIII. La guerra se extiende desde 1852 a 1876 y son las tierras navarras, las Vascongadas, el Maestrazgo y Cataluña las que la padecen. ${ }^{13}$ Esteban decide ingresar en un noviciado de car-

12 Interesante clérigo neoclásico que sintetiza lo más destacado de la corte carolina en la España de las luces y del que los investigadores no se han ocupado como bien merece, interesantes datos biográficos los pueden encontrar el lector interesado en la página web de la Fundación Casa Ducal de Medinaceli ya que el cardenal fue hijo del X duque don Nicolás Fernández de Córdoba y de la Cerda (1711-1739).

13 Cf. las causas del enfrentamiento, así como la compresión de los ideales en Alexandra Wilhelmsen, La formación del pensamiento político del carlismo, Madrid, Actas, 1995. 
melitas descalzos en Begoña, Bilbao, pero no encuentra su vocación, por lo que vuelve a los pocos meses de la ida.

$\mathrm{Al}$ abrirse el seminario y tras su ingreso, los progresos intelectuales son más que evidentes lo que le lleva en 1888 en su cuarto curso de teología a dar clases como pasante en ciencias, alcanzado incluso la cátedra de metafísica especial. Canta misa en 1896 y al año siguiente en Toledo se gradúa en teología. Comienza como se ve su ministerio sacerdotal en los años cercanos al desastre de 1898 con la pérdida de las últimas colonias en Cuba y con ello la desolación existencial que asola a España ${ }^{14}$ y que causaría dolor patriótico al joven sacerdote pamplonés que se presenta a las oposiciones a la canonjía magistral de la Ciudad Real donde también pasó a dar clases en su seminario durante años, siendo celebradas sus dotes de conferenciante o su autoría de pequeños libros de índole espiritual. Realizó activa labor predicadora inherente a su cargo en la catedral de Nuestra Señora Santa María del Prado que era además la sede religiosa de las cuatro órdenes militares. Es en 1903 cuando pasa al seminario de Segovia como rector y arcipreste de la catedral.

El gobierno del joven monarca Alfonso XIII le quiere presentar como obispo de Canarias, pero renuncia con vigor argumentando su labor académica y su nula experiencia pastoral. Estos planteamientos no le valdrían al ser nombrado obispo de Orense con la preconización el 14 de noviembre de 1904, su consagración en la catedral pamplonesa el 14 de marzo del año siguiente y su entrada en su diócesis el 2 de abril. Sucedía al prelado Pascual Carrascosa y Gabaldón cuyo ministerio se vivió desde 1895 a 1904.

Ilundain sabía de la impronta histórica de su territorio episcopal, sufragáneo a la archidiócesis de Compostela. Es una pequeña ciudad a la llegada de don Eustaquio que va dejando a un lado su identidad artesana para pasar en los últimos años del XIX hasta bien entrado el $x x$ tras su designación como capital de provincia y la llegada del ferrocarril desde Vigo a una urbe donde nace una potente burguesía formada principalmente por emigrantes castellanos.

Durante su episcopado orensano que se dilató durante quince años hizo gala de las cualidades que firmarían la brillantez de su ministerio tanto en Galicia como posteriormente en Sevilla: la

14 Cf. Javier Figuero - Carlos García SAnta Cecilia (eds.), La España del desastre, Barcelona, Plaza y Janés, 1996. 
preocupación por los sacerdotes tanto por su vida como por su formación; la exigencia - como en su dilatada época de profesor demostró - de una sólida formación para alcanzar el sacramento; el encuentro directo con los fieles mediante diversas visitas pastorales; un cuidado exquisito para el sostenimiento de los templos y cuidado de sus bellezas artísticas; y, por último, la vida litúrgica, sentida y rica, con una vibrante devoción a la Santísima Virgen. Sus enemigos le lanzarían en cara los sucesos de Usera en 1909, cuando el obispo decidió retirar el baldaquino del monasterio por motivos de seguridad y ante la oposición del pueblo hubo de intervenir la guardia civil con el resultado de nueve muertos y heridos. Las fuerzas del orden fueron enviadas por el gobernador civil, responsable del desastre, que fue cesado por el ministro de la gobernación por lo que los lamentables sucesos no tuvieron relación alguna ni en origen, ni en disposición y menos en acción con el obispo auriense. ${ }^{15}$

La tarde del 12 de noviembre de 1920 un telegrama de la nunciatura apostólica llega al palacio arzobispal, comunicándole al prelado hispalense Enrique Almaraz y Santos su traslado a Toledo como primado de España. Don Enrique sabe que es un deseo del papa Benedicto XV, su amigo desde los tiempos de Giacomo Della Chiesa como secretario de la nunciatura en Madrid, respaldado por el rey. Va a sustituir en la ciudad imperial a Victoriano Guisasola y Menéndez, cuya estancia toledana ha abarcado desde el año 1914 hasta su muerte el 2 de septiembre de 1920. Uno de sus méritos personales era haber impulsado el nacimiento de corrientes políticas para el sostenimiento de la democracia cristiana española. ${ }^{16}$

A pesar del ascenso, Almaraz está triste, ha querido mucho a Sevilla y Sevilla lo quiso, así en 1917, tan solo un año antes de la celebración de sus bodas de plata episcopales con el concurso de un gran número de obispos, autoridades y fieles, fue nombrado hijo adoptivo de la ciudad.

15 En una movida campaña orquestada por la prensa anticlerical Ilundain fue esclavo de graves insultos y menosprecios que aún son esgrimidos por el partidismo. No se pudo encontrar una sola prueba contra él, evidente por su sana inocencia. Preparo un trabajo sobre el ministerio en Orense de don Eustaquio.

16 Cf. un apurado análisis sobre la labor toledana de Guisasola, así como los principales hitos de su biografía en Ángel Fernández Collado, Los Arzobispos de Toledo en la Edad Moderna y Contemporánea. Episcopologio Toledano. Toledo, Cabildo Primado de la Catedral de Toledo, 2017, 205-208. 
Sabedores de la ida de don Enrique a Toledo las principales autoridades civiles y eclesiásticas sevillanas le envían cartas de felicitación, aunque quedará algunos meses más bajo la sombra de la Giralda, pues tendrá inusitado interés en solucionar un proyecto de cesión a la ciudad de los jardines y parte del palacio de San Telmo para su utilización con vistas a la exposición, ya en el horizonte de su celebración, tarea que sin embargo caería en los hombros de su sucesor. ${ }^{17}$

Almaraz marcha a Toledo en la primera quincena de julio de 1921 y se manifiesta de nuevo el cariño de los sevillanos que están muy satisfechos de su pontificado, como le dice en solícitas palabras el deán catedralicio que encabeza la comisión de despedida oficial de todos los estamentos eclesiásticos el 29 de junio en el salón del trono del palacio arzobispal. ${ }^{18}$

Tras la marcha de Almaraz, la sede vacante, tras la lectura de la bula pontificia del 4 de julio de nombramiento del prelado, queda en manos del provisor y deán de la catedral, que toma por poderes el ministerio del nuevo arzobispo ya preconizado desde diciembre, que sin embargo no puede arribar a Sevilla hasta el 16 de septiembre, pues estando en Madrid le asaltan unas fiebres que le hacen convalecer todo el verano en Pamplona de donde era originario. El nuevo arzobispo de Sevilla es Eustaquio Ilundain hasta entonces obispo de Orense. ${ }^{19}$

Sevilla esperó a Ilundain en la estación de Plaza de Armas el 15 de septiembre de 1921, con autoridades encabezadas por el capitán general del ejército, el infante don Carlos de Borbón. Ilundain quedaría más que satisfecho con la calurosa bienvenida de los ciudadanos que lo vitorearon durante el recorrido oficial por las principales calles céntricas hasta la entrada a la Catedral por la Puerta del Príncipe, con estación en la capilla de la Virgen de la Antigua y laudatorios de acción de gracias. La jornada acabó con la despedida a las autoridades y sevillanos presentes en el salón principal de su palacio arzobispal. ${ }^{20}$

Al día siguiente, fue celebrada otra fastuosa jornada con la entrada solemne en la catedral a la que pese a la corta distancia Ilundain

17 Las cartas de felicitación y la problemática de la cesión de San Telmo en ACS, Autos. Libro 231 (1918 - 1 semestre 1921), F. 215-216 y 238.

18 Ibidem, 221vto.

19 Cf. ACS, Autos, Libro 232 (2 semestre 1921-1925), F. 2, 3, 4, 7, 15 y 16 vto.

20 La entrada del nuevo arzobispo en Sevilla es trazada con absoluta precisión por TOVAR, Ensayo biográfico, 237-239, y en el número extraordinario 964 del BOAS dedicado íntegramente al nuevo prelado con fecha 20 de septiembre de 1922. 
fue en "lujoso carruaje", haciendo la entrada por la Puerta Principal donde el Señor Deán le dio a besar el Lignum Crucis de Constantino y don Eustaquio juró los estatutos de la Santa Iglesia, antes de pasar al altar mayor en exuberante procesión. Las primeras palabras de Ilundain a sus fieles que llenaron la catedral fueron recibidas con"alegría en el alma". ${ }^{21}$ España, mientras tanto, sufría un deterioro en su prestigio con el desastre de Annual en la guerra marroquí el mes de julio, don Eustaquio desde Madrid mandó se celebrasen rogativas por el curso del conflicto y sufragios por los fallecidos que continuaron alternativamente hasta la firma de la paz en $1927,{ }^{22}$ el arzobispo hispalense tuvo el gran acierto de no definir el conflicto como religioso con enunciados cercanos a la Cruzada, reconociendo tan solo su talante político, que al paso de los años quedaría en nada y para nada.

El prelado navarro que sabía, listo era, que se hablaba por los mentideros sevillanos de su integrismo y tradicionalismo político, lo que podía servir de freno a los confiados sevillanos desde la época de Almaraz, comenzó pronto a manifestar una pujante capacidad de trabajo con una vívida visita pastoral a Jerez, Huelva, Écija y la propia Sevilla desde octubre de 1921 a mayo de 1922, recogiendo la prensa y el boletín del arzobispado el fervor de las poblaciones visitadas y la celebración sacramental de un gran número de confesiones y de mil confirmaciones..$^{23} \mathrm{Su}$ labor en los primeros años fue ímproba y a la vez muchas veces ingrata, ya que consideraba que su territorio pastoral, encabezado por la histórica ciudad se encontraba demasiado laxo en el sostenimiento de la fe y aún más en la manifestación de la religiosidad popular con su cúspide en la semana santa edulcorada de asfixiante folklore que le hacía perder su autenticidad. La mentalidad alegre de los años veinte en la sociedad de la confianza venía respaldada también en Sevilla por el horizonte de la celebración de

21 ACS, Autos, Libro 232, F. 14vto y 15. Para el ritual de entrada de los arzobispos en la catedral, del mismo archivo la sección III. Liturgia, Libro 102: Extractos de los libros de ceremonias.

22 Entre los abundantes estudios de la guerra de Marruecos es vivaz y sorprendente con tono periodístico y los testimonios de propios actores del conflicto el de Manuel LEGINECHE, Annual. El desastre de España en el Rif. Madrid, Alfaguara, 1996. Digna de mención por su interés y calidad histórica e intuitiva la reciente obra de Daniel Macías Fernández (ed.), A cien años de Annual. Madrid, Desperta Ferro Ediciones, 2021.

23 Cf. un apurado análisis de las primeras misiones en JAVIERRE, Historia de las diócesis, 386-387. 
una exposición universal, loable idea que podía servir de anhelo económico para la urbe y de fuerte eslabón para su proyección urbanística que aún vivía en los arcaísmos novecentistas.

Precisamente en relación con esta exposición iberoamericana de 1929 el cardenal escribiría anales de esplendor, los más solemnes de su pontificado, al darle a la misma un indudable sentido religioso que el mismo purpurado había expuesto a Pío XI en la visita ad limina de 1927, donde explicó al pontífice la preparación de un congreso mariano, la coronación de la Virgen de la Antigua y una asamblea eucarística. El papa, satisfecho por las ideas del prelado hispalense, lo bendijo fraternalmente y lo nombró delegado para el congreso mariano. La amistad entre Pío XI e Ilundain sería estrecha y abarcaría todo el pontificado sevillano del navarro como demuestra que el papa el 19 de diciembre de 1936, en las difíciles fechas de los primeros meses de la guerra civil, en audiencia otorgada al primado de España, Isidro Gomá, enviaría una bendición especial y afectuoso saludo al cardenal arzobispo de Sevilla. ${ }^{24}$

El congreso contó con nutrida asistencia de mariólogos y especialistas que derivaría en la publicación de unas completas actas donde se recogieron los estudios presentados, quedando en la memoria la apoteósica procesión magna de clausura ${ }^{25}$ y en las sesiones la coronación de la Virgen de la Antigua, pintura mural catedralicia de mucha devoción para Ilundain y en tiempos de la conquista de América, siendo la segunda coronación canónica que se celebraba en la ciudad tras la de Nuestra Señora de los Reyes en el pontificado del beato cardenal Marcelo Spínola en 1904.

$\mathrm{Al}$ año siguiente, en la clausura de la exposición, organizó unas jornadas de exaltación eucarística con solemne ceremonia litúrgica en la Plaza de España, corazón del certamen. ${ }^{26}$ El trabajo realiza-

24 Cf. Santiago NAVARRO DE LA FUENTE, La Santa Sede y la guerra civil. Los representantes del Papa en la España en conflicto (1936-1938). Sevilla, Editorial Universidad de Sevilla, 2019, 180.

25 Cf. Crónica oficial del congreso mariano hispanoamericano de Sevilla. Sevilla, Imprenta Sáez Hermanos, 1929.

26 La labor de la Iglesia hispalense en relación con la exposición del veintinueve es excelentemente analizada por José Leonardo RUIZ SÁNCHEZ: "La iglesia de Sevilla y la Exposición Iberoamericana de 1929", en Amparo GraCIANI García - Concepción Langa nuño (cord.), La exposición iberoamericana de Sevilla. Aportaciones para la historia. Sevilla, Editorial Universidad de Sevilla, 2019, 155-178. 
do para la exposición fue recompensado por el rey con el collar de Isabel la Católica que también obtuvo el general Primo, siéndoles impuesto a ambos en la misma ceremonia, celebrada en el altar mayor de la catedral sevillana el 12 de octubre de 1929, fiesta nacional, por el infante don Carlos de Borbón en nombre del rey. A petición de Ilundain, el acto culminó con el rezo de la salve en la capilla de la Virgen de la Antigua, manifestando así una vez más su devoción mariana. ${ }^{27}$ La doble concesión poseía junto a su importancia premial, máximo grado de la orden, un alto sentido simbólico al haber sido creada por Fernando VII el 14 de marzo de 1815 con el nombre de Orden Americana de Isabel la Católica con el fin de"premiar la lealtad acrisolada y los méritos contraídos en favor de la prosperidad de ambos territorios". ${ }^{28}$

Su ímproba capacidad para la restauración artística y levantamiento de templos quedó más que demostrada en tierras sevillanas como los estrenos de la Concepción en Nervión, del Corpus en la Palmera, barrio nacido al compás de la exposición, el del Cerro del Águila o el del barrio obrero de San Jerónimo, capacidad pastoral que extendió a la archidiócesis con el de San Enrique en Jerez, el del Sagrado Corazón en el barrio del Polvorín en Huelva y en el aljarafe sevillano el de San Juan de Aznalfarache, o la terminación del templo de Villanueva de los Castillejos que llevaba más de un siglo de construcción.

Ilundain fue también un hombre de entendimiento político, como toda la iglesia sevillana y española recibió al directorio militar con afecto, demostrado con cartas autógrafas y celebraciones litúrgicas, pero es más sobresaliente su prudencia y buen hacer tras la caída de la monarquía y los difíciles años de la república con sus inevitables, por esperados, conflictos anticlericales. Al ser nombrado el sevillano Diego Martínez Barrios ministro y al volver en visita a Sevilla en mayo de 1931, el cardenal quiso visitarlo en su domicilio que a la vez era sede de la orden masónica, en un acto que volvió a valorar las posibilidades del arzobispo para ser enviado como primado a Toledo que el propio Ilundain rechazó. La visita fue digna de relato: $\mathrm{Su}$ Eminencia fue en su coche oficial a la vivienda del político y al no entrar el vehículo por la estrechez de las calles el prelado la alcanzó a

27 Cf. HMS, Diario ABC. Sevilla, 13 de octubre de 1929. Es en este año cuando nace el periódico sevillano al compás de la exposición iberoamericana.

28 Alfonso CEBALLOS-ESCALERAY GILA, La Real y Americana Orden de Isabel la Católica (1815-1915). Madrid, Boletín Oficial del Estado, 2015. 
pie, no encontrándose don Diego en su casa en aquellos momentos. Enterado el ministro, le devolvió la visita al arzobispo en su propio palacio donde mantuvieron un diálogo proclive al entendimiento, ${ }^{29}$ arzobispo que se enfrentó a los desmanes de los incendios de iglesias y persecución del clero en 1931, pero tuvo a lo largo de aquellos años republicanos una sobria intención de diálogo que mereció el elogio del propio Martínez Barrios en sus memorias:

Si se repasa la historia de las relaciones y el poder civil durante toda la edad contemporánea hay que convenir que nunca se produjo una iniciativa cerca del estado tan franca y amistosa como la que asumió el cardenal arzobispo de Sevilla aquella plácida tarde del mes de mayo [...] Conservo viva la impresión que hubo de causarme el sencillo atuendo del despacho donde me recibió el arzobispo. Pulcritud y modestia. El Cardenal mismo, si despegado y frío, daba la sensación, remarcable, de nobleza y autoridad. No volví a verle hasta 1936 cuando ya sonaban los vientos homicidas. En su saludo cortés de entonces, era yo presidente interino de la república, chispeó un oculto reproche, el recuerdo de la tentativa de 1931, desaprovechada por los gobernantes de la república. Dígome, contrito, que el cardenal, dando aquel paso adelante fue mucho más prudente y previsor que nosotros. ${ }^{30}$

Son unas palabras fundamentales para valorar la valía personal de Ilundain y también evidente prueba de que parte importante de la Iglesia española quiso colaborar con la república; y un político comprometido con la misma, nada religioso, por cierto, reconoce la irresponsabilidad de los gobernantes por no saberla aprovechar. Otra interesante aportación de Martínez Barrios en sus recuerdos es la descripción atinada que realiza sobre los arzobispos de Sevilla que ha conocido, testimoniando la santidad de Marcelo Spínola en la que dejó incluso dotes proféticas asegurando que llegaría a santo, la bonhomía de Enrique Almaraz y su afición a los dulces, y el saber dialogante de Eustaquio Ilundain que desde el principio fue recibido con reticencias por el clero y los fieles, pero que supo ganarse la ciudad en los primeros tres años de mandato, según don Diego, que concluye con énfasis"fue uno más de los ilustres arzobispos de Sevilla". ${ }^{31}$

29 Cf. los pormenores en TOVAR, Ensayo biográfico, 685-687. Lo refiere con su gracejo habitual JAVIERRE, Historia de las diócesis, 398-399.

30 Diego Martínez Barrios, Memorias. Barcelona, Planeta, 1983, 36.

31 Ibidem, 17-18. Los recuerdos del político sevillano, importantes para entender aquel período de nuestra historia, se confunden al incluir al arzobispo Castellote, 
Martínez Barrios fue también político dialogante y alcanzaría más puestos importantes en la política republicana; mantuvo el ministerio de comunicaciones pocos meses, para pasar al de la gobernación de 1933 a 1935, ministerio que compaginó con el de la guerra. En la guerra civil, fue el presidente de las cortes y llegaría a ser presidente de la república española en el exilio desde 1945 hasta su fallecimiento en París el 1 de enero de 1962.32

La relación de entente cordial con el republicanismo imperante del cardenal arzobispo de Sevilla, sin olvidar en modo alguno los deberes y las quejas por los injustos excesos contra la Iglesia queda demostrada en históricas fotografías como en la que se le ve satisfecho al enseñar el patio de los naranjos catedralicio a don Manuel Azaña y esposa o el haber ido en persona a despedirlos tras su marcha a Madrid.

La sublevación de 1936 triunfó en Sevilla en pocos días de julio y el 15 de agosto Ilundain presenció la izada desde el balcón del ayuntamiento de la bandera monárquica junto a Franco y Queipo de Llano, aunque no realizara demasiadas declaraciones públicas a favor de los golpistas, ni su rostro, envejecido y demacrado, reflejase algún tipo de satisfacción..$^{33}$ El arzobispo siguió con su vida pastoral y el 25 de julio de 1937 presidió desde la catedral, y junto a Queipo, el desfile de las tropas por el restablecimiento del patronato de Santiago sobre España.

Al día siguiente, al visitar la parroquia trianera de Santa Ana en la fiesta grande de su titular, tuvo sudor, fiebre y algo de asfixia, lo que fue anticipo de una bronconeumonía que no pudo superar, muriendo el día de san Lorenzo. Se piensa que este estado de postración física durante todo ese verano fue debido a los efectos de un accidente automovilístico al chocar su vehículo con un árbol en junio anterior, tras volver de visita pastoral a Estepa. Fue enterrado, según su deseo, a los pies de la Virgen de la Antigua en el lado del evangelio, donde espera la resurrección de la eternidad. ${ }^{34}$ El legado pontificio para su

electo de Sevilla y fallecido antes de tomar posesión, entre los pontificados de Almaraz e Ilundain, cuando su nombramiento acaeció en 1906 tras la muerte de Spínola y antes de la llegada de Almaraz.

32 Cf. Leandro ÁLVAREZ REY, “Diego Martínez Barrios”, Andalucía en la historia 1 (2003) 83-87.

33 La prensa nacional recogió la noticia en diferentes fuentes y se hizo icónica la fotografía de Ilundain junto a Franco y a Queipo. Véase por ejemplificar el $A B C$ de Sevilla, 16 agosto 1936.

34 Cf. BOAS, Número especial de 1 de septiembre de 1937 dedicado a la figura y al sepelio del Cardenal. 
funeral fue el cardenal Segura, exiliado en Roma, que pronto sería nombrado su sucesor. ${ }^{35}$

Si la heráldica es ciencia que ilustra sobre un personaje, en el escudo del cardenal parece estar reflejado toda la fe, la devoción, la luz y la constancia de su vida: lo preside en extenso campo superior el Corazón de Cristo y el inferior queda dividido en dos: a la diestra el león y cadenas, representación de su querida tierra navarra y en la siniestra el símbolo de la Virgen. Él mismo lo explicó en atinadas palabras al elegirlo tras tomar posesión de la diócesis de Orense:

Mis propósitos están condensados en el escudo de armas que he escogido. El león rampante y las cadenas que figuran en uno de sus cuarteles representan la fortaleza en la fe que animó a los navarros en la formidable batalla de las Navas de Tolosa y la cual yo ansío tener hasta exhalar el último suspiro. En el otro cuartel está el monograma de María y por debajo aquellas palabras benedictísimas dirigidas por el Arcángel Gabriel a nuestra Madre querida para anunciarle la Encarnación del Verbo: Ave María. Coronándolo todo y como llenándolo y abarcándolo todo aparece el Corazón Dulcísimo de Jesús símbolo augusto del amor. ${ }^{36}$

Su lema está tomado de la primera carta del apóstol san Pablo a los corintios: Omnia honeste et secundum ordinem fiant ("Que todo se haga decentemente y en orden": 1 Cor 14,40); orden que buscó y obtuvo para escribir, a juicio de quien esto escribe, uno de los mejores pontificados de la Iglesia española contemporánea.

\section{CONSAGRACIÓN O DEDICACIÓN DE UNA IGLESIA: UNAS PALABRAS DE APROXIMACIÓN}

En el actual ceremonial de los obispos aprobado 14 de septiembre de 1984 se define la catedral como"aquella en la cual el obispo tiene situada la cátedra, signo del misterio y de la potestad del pastor de la iglesia particular, como también signo de unidad de los creyentes en aquella fe que el obispo anuncia como pastor de la grey"37

35 Cf. el nombramiento de Segura y su labor en la archidiócesis de Sevilla en Francisco GIL DELGADO, Pedro Segura. Un cardenal de fronteras, Madrid, BAC, 2000.

36 Miguel Ángel GONZÂLEZ GARCÍA, "La heráldica auriense del obispo Ilundain", El faro de Vigo. Vigo, 27 de enero de 2019.

37 Consulto el Ceremonial publicado por la Conferencia Episcopal Española en la Biblioteca de Autores Cristianos en 2019. 
Como establece también el ceremonial, tiene que estar dedicada a Dios con una solemne celebración según una muy antigua costumbre de la Iglesia que ha de tener un titular: la Santísima Trinidad; Nuestro Señor Jesucristo, con la invocación de un misterio de su vida redentora admitido en la liturgia; la Santísima Virgen, con otra advocación de refrendo eclesiástico; los Santos Ángeles o un santo, incluido en el martirologio romano, pero no un beato que tendría que tener dispensa especial de la Sede Apostólica.

En la liturgia de dedicación, la actual algo adaptada a la celeridad de los tiempos, se bendicen y erigen todo lo que se encentra en ella, como la fuente bautismal, la cruz, las imágenes, el órgano, las campanas y las estaciones del Vía Crucis. Solo se necesita una bendición o erección, sin que sea conveniente otra ceremonia del mismo efecto.

Este rito de consagrar una iglesia ha sido llamado siempre dedicación y, según sostiene Eusebio de Cesarea (c.263-339), en tiempos de Constantino era una liturgia de índole privada que alcanzó la manifestación pública tras la conversión del emperador.

Algunos investigadores fijan su génesis alrededor del año 105 y precisan su atribución al papa san Evaristo (100 o 101 - 108 o 117) que estableció el modo de celebración, basándose con seguridad en alguno ya existente. La tradición divulga la consagración de la casa de santa Cecilia por el pontífice san Urbano i (222-230) que de manera valiente se enfrentó para defender los intereses de la iglesia a Hipólito de Roma que se había proclamado pontífice, siendo por tanto el primer antipapa de la historia. San Urbano convirtió a Cecilia, a su esposo Valeriano y a Tiburcio en el río Tíber, por lo que tras el martirio de la futura patrona de los músicos dedicó la casa donde reposaban sus venerados restos y donde también dormía el descanso eterno su predecesor Calixto I (217-222), valedor ante Dios, como Lucía, de la sangre derramada por la fe y del laurel de la santidad. Urbano también gozó de la palma martirial el 22 de mayo de 230. San Marcelo (308-309) papa muerto en el exilio que entregó su labor a la reedificación de los templos destruidos tras la persecución, dedicó una iglesia en la casa de santa Lucina, matrona y mártir romana del siglo I, convertida a la fe de Cristo junto a su familia y cuyas reliquias descansaron en las grutas que ella había hecho construir para enterrar a otros mártires. Es después del siglo IV, cuando es tomada la costumbre que la ceremonia solo sea realizada por un obispo mediante un ceremonial suntuoso que era completado con la celebración de 
una octava. Se aprobó también que, al no poder asistir el prelado, las iglesias lejanas y situadas en espacios de difícil acceso fuesen solo bendecidas por un sacerdote comisionado por el obispo que atendiendo a necesidades propias de los feligreses podía ser comisionado también para consagrar las fuentes bautismales para la celebración del sacramento.

El catolicismo heredaría esta tradición litúrgica de la dedicación del mundo hebreo con el que hunde raíces de significación y simbología. En las Sagradas Escrituras encontramos dedicaciones del tabernáculo, de los altares de los templos y de incluso casas particulares de sacerdotes y levitas. Lo que sí parece que es de origen cristiano es celebrar la fiesta de aniversario de la dedicación en cada diócesis con el recuerdo con la realizada en la catedral como templo de todos. No celebran el aniversario las iglesias que solo son bendecidas. ${ }^{38}$

En el calendario romano se celebra anualmente la dedicación de la catedral de Roma cada 9 de noviembre. Su título es Archibasílica del Salvador y de los santos Juan Bautista y Juan Evangelista. La llamada "madre y maestra de todas las iglesias del mundo" fue dedicada por el papa San Silvestre (314-335) que es venerado como santo además por las iglesias ortodoxas, armenia, luterana y anglicana, el 9 de noviembre del año $324 .{ }^{39}$

El rito de celebración adquiría sintagmas de bella magnificencia, como veremos más extensamente en la descripción de la dedicación de la Catedral de Sevilla por Ilundain en 1932, como se dijo antes la complejidad ceremonial, se adaptó a la necesidad actual en las normas pontificales de san Juan XXIII emanadas el año 1961en primer lugar y por san Juan Pablo II en 1984, coincidente con el nuevo código de derecho canónico promulgado un año antes. El nuevo ceremonial de los obispos puede ser considerado como la culminación de la reforma del Vaticano II en el espíritu de la constitución Sacrosanctum Concilium. ${ }^{40}$

38 Una obra de importancia considerable sobre el desarrollo histórico y ceremonial en la dedicación de las iglesias es la de Ramón NAVARRo, La dedicación de la iglesia: Eclesiología de celebración a lo largo de la historia. Barcelona, Centro de Pastoral Litúrgica, 2019. Me ha servido de copiosa fuente de información.

39 Cf. José Luis Martínez Puche, "Dedicación de la Basílica de San Juan de Letrán”, en Nuevo Año Cristiano, noviembre. Madrid, Edibesa, 2001.

40 Para seguir la renovación litúrgica es de obligada lectura las memorias de su principal hacedor, Anibale Bugnin, La reforma de la liturgia (1948-1975), Madrid, BAC, 2013. 
Los ceremoniales de la dedicación, a lo largo de la historia eclesial, han poseído reiterada presencia de simbología, contenido y sapiencia mistagógica cuyo estudio se hace imposible en este trabajo por normas de espacio y cuyo suntuoso rito veremos con detalle al analizar la consagración de la catedral hispalense.

\section{SEVILLA EN 1932. LA SEGUNDA REPÚBLICA ENTRE LA ILUSIÓN Y LA DECEPCIÓN. ${ }^{41}$}

Una de las múltiples manifestaciones de triunfo y devoción monárquica entre sus súbditos en el reinado de Alfonso XIII fue la exposición iberoamericana de Sevilla de 1929, una empresa en común del rey, del pueblo de Sevilla y del jefe del Directorio Miguel Primo de Rivera, figura esencial para el desarrollo de la muestra. ${ }^{42}$ Su marcha al exilio preconizó el fin de la corona alfonsina tras los gobiernos inestables de Berenguer y Aznar que solo pudieron alargar brevemente la agonía.

Las elecciones municipales del 12 de abril de 1931 fueron una llamada de atención a los partidos tradicionales, no así en capitales de provincia, lo que llevó al rey a tomar el camino de exilio para erradicar, según su propio mensaje de vertiente conciliadora, un posible y temido enfrentamiento entre españoles. Hoy sigue pareciendo irreal que por un plebiscito de índole local y manipulado en muchas poblaciones se cambiase todo un sistema de gobierno.

${ }^{41}$ El profesor de la universidad sevillana Juan Manuel MACARRO VERA ha dedicado gran parte de su vida investigadora al estudio de la segunda república en Sevilla con un excelente libro: La utopía revolucionaria. Sevilla en la segunda república. Sevilla, Diputación, 1985 (adaptación para el gran público: La Sevilla republicana, Sevilla, Sílex, 2003). Cf. también Alfonso Braojos GARrido - María PARIAs SAINZ de Rosas - Leandro Állvarez ReY, "El ensayo republicano, revolución y reacción en el sentir de la utopía (1931-1936)", en Francisco Morales Padrón (dir.), Historia de Sevilla, Sevilla, Publicaciones de la Universidad de Sevilla, 1992, 499-520. Quien busque un estilo dinámico y periodístico puede leer los dos tomos del prolífico y recordado Nicolás salas, Sevilla fue la clave. República, alzamiento, guerra civil. Sevilla, Castillejo, 1992.

42 Cf. un análisis del gobierno de Primo en lo referente a Sevilla en Leandro ÁlvarEZ REY, Sevilla durante la dictadura de Primo de Rivera, la Unión Patriótica. Sevilla, Diputación Provincial, 1987. 
El nuevo régimen es recibido con esperanza por gran parte de la población encaminada a vivir otra época, pero por desgracia, el antagonismo de las llamadas dos Españas alimentó el enfrentamiento general, con un anticlericalismo violento por parte de las izquierdas y un camino al extremismo fascista por las derechas, que llevaría irremediablemente a la guerra civil. La república fracasó no solo por la ceguera partidista de los gobernantes, sino también por una oposición tenaz de círculos importantes que se unieron para erradicar de cualquiera manera su triunfo.

La mayor parte de Sevilla abrazó la república y en las elecciones de cortes constituyentes del 28 de junio la victoria de la coalición republicano-socialista fue clara y rotunda, con una participación electoral mucho más elevada que en las de abril, lo que bien podía considerarse la ilusión del ciudadano en una nueva oportunidad. Tras estas elecciones se había aclimatado de manera oficial el nuevo sistema en la cuidad de la Giralda, con el cargo de alcalde para el partido radical y el de la diputación para el socialista, lo que influyó para una necesaria vitalización de los partidos de derecha que habían presenciado como el poder se les escapaba.

El anticlericalismo de los nuevos gobernantes poco tardó en quedar manifiesto con la separación taxativa de la Iglesia y el Estado, el 5 de mayo los obispos dejan de formar parte de la instrucción pública y al día siguiente la enseñanza de la religión pierde su obligatoriedad en las escuelas. Son dolorosos los incidentes de mayo, con el ataque desaforado de la prensa de izquierda a las autoridades eclesiásticas y la proliferación de enconados disturbios con quemas de iglesias y conventos, sucesos que en Sevilla se cobran la quema de la capilla de san José y otros incidentes en la provincia, como los asaltos a las parroquias de Coria y Lora del Río. ${ }^{43}$

Por la dramatización del ambiente, el primado de España y cardenal arzobispo de Toledo, Pedro Segura y Saénz, es llamado a consulta a Roma por Pío xi el 13 de mayo. ${ }^{44}$ El cardenal es acusado de servir a intereses contrarios a la república, por lo que, acuciado

43 Cf. un intento de compresión de la política antirreligiosa y la relación de los incendios y asaltos de iglesias en Manuel Álvarez Tardío, Anticlericalismo y libertad de conciencia. Política y religión en la Segunda República Española. Madrid, Centro de Estudios Políticos y Constitucionales, 2002.

44 Cf.Vicente CÁrcel OrTí, Pío Xi entre la Republica y Franco. Angustia del papa ante la tragedia española. Madrid, BAC, 2008. 
por la presión y para servir, como toda su vida, al bien de la Iglesia pone su cargo a disposición del pontífice, marchando a un exilio en Roma de donde volvería como arzobispo de Sevilla en 1937.45 Ilundain, desde Sevilla, intentó, como ya se dijo, ser un padre para todos mostrando una hábil actitud diplomática en sus relaciones con los políticos, siendo incluso guía por la catedral sevillana del presidente de gobierno Manuel Azaña el 31 de diciembre, con el que además no le importó fotografiarse, mostrando el prelado una actitud bastante satisfactoria. ${ }^{46}$

No empezó con buenas noticias para el bien común el año 1932 en Sevilla, que fue sacudido en enero por una huelga general entre los días 25 y 26 en la que se llevan a cabo enfrentamientos entre pistoleros anarquistas y la fuerza pública, con el doloroso resultado de un muerto y varios heridos, teniendo que incluso recurrir la autoridad al uso de tanques para sofocar la rebelión. El paro obrero volvió a recrudecer el conflicto que ya se vivió en julio anterior tan solo tres meses después de la llegada de la república que, aunque sometido a mucha desinformación de medios, no tuvo consecuencias graves en la seguridad de la población, alcanzando notoriedad el ya mítico fusilamiento del bar casa Cornelio, aledaño al arco de la Macarena, que fue destruido con veintidós cañonazos con granadas rompedoras, quedando en total ruina el 23 de julio el reconocido lugar de encuentro del movimiento anarquista. ${ }^{47}$

Durante todo el año, la seguridad en las calles era inexistente y las discusiones terminaban en choques violentos, produciéndose

45 Cf. Jorge López Telón, 1931 Cardenal Pedro Segura. Toledo, Cabildo Primado, 2018.

46 Cf. las circunstancias de la visita en Tovar, Ensayo biográfico, 685-687. El biógrafo casi indica que el prelado fue obligado a hacer de guía tras llamada telefónica del gobernador y a petición del propio presidente. La publicación de la obra en Pamplona parece justificar los recelos de Tovar en mostrar alguna relación de su cardenal con los prebostes de la república.

47 La noticia del bombardeo del bar es mostrada con todo su irónico dramatismo en el diario $A B C$ de Sevilla del 24 de julio de 1931. Algunos autores con clara tendencia achacaron este ataque al golpista Queipo cinco años después. Incluso el autor José María García MárQueZ culpa los incidentes de mayo de 1931 a una manipulación de la derecha en su libro: La semana sangrienta de 1931 en Sevilla, entre la historia y la manipulación. Sevilla, Aconcagua Libros, 2019. Una eficaz aproximación al auge del izquierdismo que hizo que la cuidad se le llamara pronto como La Roja en el atractivo libro de Nicolás Jesús SALAS, El Moscú sevillano. Sevilla, Universidad, 1990. 
atracos a las clases pudientes y una unión más consolidada entre comunistas y anarquistas a partir del mes de mayo. ${ }^{48}$

El 2 de marzo fallece en el convento de las hermanas de la Cruz su fundadora, Ángela Guerrero González, lo que originó un intenso duelo en la ciudad, siendo venerado su cuerpo por todas las clases sociales, testimoniaron su sincero cariño a la que había entregado su vida a Dios, mediante el amor a los más necesitados e infelices de Sevilla, con la fundación de las hermanas en 1875, a las que regaló una vida de inspiración mística y santa. Una comisión del cabildo manifestó su pesar a las hermanas en el cenobio y los capitulares tras le petición del párroco de San Pedro deciden celebrar un solemne funeral por su alma el sábado 12 de marzo por la tarde que fue masificado y devoto, ${ }^{49}$ a las pocas jornadas y escuchando el sentir y admiración general el ayuntamiento de izquierdas rotuló con su nombre la calle del convento. ${ }^{50}$

A la llegada de la primavera, las cofradías deciden no realizar las estaciones penitenciales argumentando su negativa a la persecución religiosa que se sufría, aunque la reivindicación no carecía de argumentos. Otro motivo importante añadido era que el ayuntamiento había decidido no realizar la subvención de ayuda a las hermandades que salían y pasaban por la carrera oficial. Esta subvención o ayuda había quedado establecida en la segunda mitad del siglo XIX, al revestirse la fiesta pasional de indudable interés para la llegada del turismo internacional. ${ }^{51} \mathrm{~A}$ pesar de reuniones oficiales que intentaron presentar motivos disuasorios para no seguir con una decisión tan rotunda y con tanta repercusión para los cofrades y para el comercio y ciudadano, los hermanos mayores y sus juntas de gobierno no declinaron la negativa adoptada y no se celebró la Semana Santa en las calles, solo hizo estación, como es bien sabido, la cofradía trianera de la Estrella el jueves santo, cuyo cortejo penitencial sufrió algunos incidentes de pequeña consideración. Este episodio cofradiero de 1932, como ocurre con todos los vividos en la república, es aún motivo de

48 Cf. Miguel Ángel Calvo Calvo, Crímenes sociales y pistolerismo en la Sevilla de 1932: entre la reacción y la revolución. Sevilla, 2006, <https://idus.us.es/handle/11441/61261> [consulta: 12 septiembre 2021].

49 Cf. ACS. Autos, Libro 234 (1931-1938), F. 53.

50 Cf. José María Javierre, Madre de los pobres. Madrid. Alameda, 1969, 312-316.

51 Cf. Rafael Jiménez SAmpedro, La Semana Santa de Sevilla en el siglo XIIX. Sevilla, ABEC Editores, 2013. 
discusión en cuanto si la no celebración de la Semana Santa fue una sincera manifestación de protesta con la política antirreligiosa de las autoridades o si más bien fueron más decisivos los motivos económicos por la no ayuda de las subvenciones. Sí se celebraron, con la solemnidad acostumbrada, las ceremonias litúrgicas del triduo sacro en la catedral, presididas por el Cardenal, aunque sin la asistencia de la corporación municipal, incumpliendo así lo que estaba establecido en su propio ceremonial desde el año 1859 tras una concordia firmada por los dos cabildos, catedral y secular, para regular la asistencia al triduo pascual de las autoridades del municipio sevillano. ${ }^{52}$

En la Sevilla de 1932, la alcaldía estaba en manos del republicano socialista don José González y Fernández de la Barrera, médico de profesión junto a sus otros dos hermanos, que la poseía desde el año anterior y la mantendría hasta 1933 al ser elegido diputado por el partido radical. Moriría en la carretera de Carmona, fusilado por los sublevados, en la noche del 10 de agosto de 1936 junto a Blas Infante, el diputado socialista Manuel Barrios, Fermín Zayas a la sazón secretario de la masonería andaluza y el teniente de alcalde Emilio Barbero. ${ }^{53}$ En la diputación, vecina con el palacio arzobispal, se encontraba como presidente Hermenegildo Casas Jiménez el primer hombre que izó la bandera republicana en el balcón consistorial y fue, aunque por breves días, el primer alcalde del nuevo régimen. Casas estaría al mando de la casa de la provincia hasta 1934, murió exilado en Méjico en 1967 y fue un socialista de ideas vinculadas al diálogo para el bien de todo y de todos, muy próximo así en la búsqueda del diálogo para el bien común a Eustaquio Ilundain. ${ }^{54}$

A los pocos días de la conclusión de la Semana Santa, el viernes 8 de abril, un incendio provocado redujo a cenizas el templo de San Julián, con la pérdida irreparable del Cristo de la Buena Muerte y de las imágenes góticas y dolorosa de la Hiniesta, esta última atribuida a Montañés o Alonso Cano. El famoso predicador capuchino Fray Sebastián de Ubrique, en gesto valeroso, logró salvar la Reserva del Santísimo y una imagen hermosísima de la Inmaculada Concepción,

52 Cf. Mauricio Domínguez Adame, Protocolo y ceremonial de la ciudad de Sevilla. Sevilla, Ayuntamiento, 2013, 399-408.

53 Cf. Paul Preston, El exterminio en la guerra civil. Barcelona, Mondadori, 2011, 57- 58

54 Cf. Julio Ponce Alberca, Andalucismo, república y socialismo. Hermenegildo Casas Jiménez (1892-1967). Sevilla, Diputación Provincial, 2002. 
también como la dolorosa perdida de origen montañesino. El incendio y sus consecuencias desolaron al mundo católico y tradicional de la ciudad y los culpables, alguno relacionado con la propia cofradía, recibieron livianas condenas penales, lo que podía hablar de connivencia de las autoridades judiciales o gubernamentales. ${ }^{55}$ No puede negarse que los años republicanos sirvieron de cortapisa para el florecimiento de la Semana Santa en las calles, pero sí sería injusto descargar la culpa en el gobierno y la autoridad y no analizar el papel, muchas veces, arrogante y soberbio de muchos representantes cofradieros que se creían con todo el peso de la religiosidad sevillana y alguno pensando tener un poder absolutamente estéril. En 1933 no se celebró la fiesta procesional, en 1934 salieron trece cofradías, lográndose la ansiada normalidad en 1935 y $1936 .{ }^{56}$

El cabildo catedral, con la anuencia del cardenal, decidió que la procesión del Corpus tuviese la misma grafía del año anterior: el Santísimo salió bajo palio por gradas altas de la catedral, formato que se extendería hasta 1934. En 1935 el Sacramento procesionaría en la custodia chica, también bajo palio y ese año se incorporaron las autoridades hispalenses al histórico cortejo, la gran fiesta religiosa de la ciudad en la edad moderna. La celebración eucarística de 1936, con la inminente llegada de la guerra civil, ya fue celebrada, siguiendo las normas de seguridad, en el interior del recinto catedralicio. ${ }^{57}$

La otra gran procesión vertebral de la religiosidad sevillana, la de la Virgen de los Reyes el 15 de agosto fiesta de la Asunción de la Virgen a los cielos, tampoco salió a la calle, discurriendo la procesión por las últimas naves interiores de la catedral los años 1932, 1933 y 1934, volviendo a salir a la calle entre el itinerario de la Puerta de los Palos a la de San Miguel y con el alborozo de los devotos en 1935, siendo escoltado el paso mariano, para impedir desmanes, por fuerzas de la guardia civil. ${ }^{58}$ En 1936 con el triunfo del alzamiento la pro-

55 Cf. Emilio José Balbuena Arriola, "El incendio de la iglesia parroquial de San Julián en 1932" en Boletín de las cofradías de Sevilla. Sevilla, Consejo General de Hermandades y Cofradías, 578 (2007) 165-171.

56 Cf. Juan Pedro Recio: Las cofradias sevillanas en la segunda república. Sevilla, Abec Editores, 2010.

57 Cf. Rafael JiméNEz SAMPEDRO, “La procesión del corpus durante la segunda república" en Boletín de las Cofradias de Sevilla 773 (2020) 502-504.B

58 Cf. Juan Martínez Alcalde, La Virgen de los Reyes, Patrona de Sevilla y de sus Archidiócesis. Historia, Arte y Devoción. Sevilla, Editorial Miriam, 1989, 47-48 
cesión adquiriría tonos patrióticos, en una época que escapa a este intento de aproximación histórica al tema de estudio.

Otro gran conflicto de 1932 es el fallido golpe de estado del general Sanjurjo, liderado y pensado desde Sevilla en el cual tomó parte un reducido número de miembros de las fuerzas armadas y que solo sirvió para potenciar el asiento del enunciado republicano que de momento y por su fracaso, se encontraría libre de pronunciamientos militares, como sucesores de los cantos tragicómicos que habían desolado al Estado en buena parte del reinado de Isabel II. La que pasó a la historia con el sobrenombre de sanjurjada fue un revulsivo para los republicanos que aprobaron seguidamente las leyes del Estatuto de Autonomía para Cataluña y la de Reforma Agraria, que habían sido tan discutidas por los conservadores y que se argumentaba había sido la principal causa del pronunciamiento militar fallido en una llamada a la unidad de España y a no perder la propiedad de tierras las clases pudientes. El gobierno también licitó medidas represoras como la depuración de funcionarios no afines, o la supresión de la jefatura de la Guardia Civil que pasó a depender del ministerio de la gobernación..$^{59}$ Sanjurjo, exiliado, volvería a reaparecer en el golpe de $1936 .{ }^{60}$

En Sevilla, cuna de la sanjurjada, la reacción del pueblo favorable al régimen e imbuido de ambición violenta no se hizo esperar. Fueron incendiados el Nuevo Casino, el Círculo Mercantil, las casas de las marquesas de Esquivel y la de Luca de Tena, mientras que otras fueron apedreadas como las del Conde de Bustillo, intentado el asalto a la redacción de periódicos conservadores como $A B C$ y la Unión, sin que por fortuna pudieran consolidarse los intentos de incendiar las iglesias de San Idelfonso, San Martín, San Juan de la Palma y el convento de las agustinas. En la provincia, también fue asaltada la parroquia del Real de la Jara, incendiadas en Gerena y Aznalcóllar, aunque se erradicaron los intentos pirómanos en Sanlúcar la Mayor, Marchena y Écija. ${ }^{61}$ Fueron tales los sucesos que el nuncio pidió relación a Ilundain que resignado mostraba su dolor por lo sucedido. ${ }^{62}$

59 Cf. Nigel Townson, La república que no pudo ser. La política de centro en España (1931-1936). Madrid, Taurus, 2002.

60 Cf. Gustau Nerín, La guerra que vino de África. Barcelona, Crítica, 2005.

61 Cf. los sucesos de Sevilla en MACARro, La Sevilla republicana, 115-124.

62 Cf. Leandro Álvarez Rey, La derecha en la Segunda República. Sevilla 1931-1936. Sevilla, Publicaciones del Ayuntamiento, 1993, 269. 
Con este telón de fondo, un fondo inestable, polémico y violento, Eustaquio Ilundain consagró la catedral de Sevilla en octubre, un puntal de su biografía muy desconocido incluso por los componentes del cabildo catedralicio hispalense, por el que merece, incluso solo por eso, pasar a la historia de la Iglesia española, donde está por derecho propio. La consagración sería para el cardenal una gran satisfacción ante los difíciles momentos que se vivían en tierras de España y en la propia vivencia del catolicismo sevillano en lo individual y en lo general. Fue valiente al fijar la ceremonia para octubre a escasos dos meses del pronunciamiento militar. ${ }^{63}$

\section{LA CONSAGRACIÓN DE LA CATEDRAL DE SEVILLA Y EL CARDENAL ILUNDAIN. UNA LITURGIA DEL SIGLO XVI EN LA ESPAÑA DE LA SEGUNDA REPÚBLICA}

Es en 1931 cuando el cardenal Ilundain escribe a Roma; son buenas sus relaciones con la sede de Pedro y le profesa simpatía personal el papa Pío XI para presentarles un ruego, una consulta y una petición. La misiva hispalense se dirige a la Sagrada Congregación de Ritos el 13 de marzo de 1931 y en ella manifiesta el cardenal que, habiéndose preocupado en hallar la fecha de la consagración de su catedral, no se había encontrado ninguna documentación al respecto tras perspicaz búsqueda; por lo que debido a ese silencio documental solicitaba permiso de la congregación para llevarla a cabo, por el bien litúrgico de su cátedra y el de sus fieles. Junto a la escasez de pruebas históricas, el prelado sevillano también sustentaba su idea en la no existencia de cruces consagratorias en los muros catedralicios del interior del recinto. Argumenta seguidamente el arcaísmo de la mesa del altar mayor, no adaptada por lo tanto a las rúbricas en uso y que en ella no habían sido colocadas las reliquias obligatorias hasta fines del siglo.

El cardenal expresa que de la antigua mezquita aljama, sobre la que se construyó la edificación actual, no quedaban restos, lo que parecía argumentar que cualquier ceremonia consagratoria anterior a la terminación de la seo a principios del XVI carecía de

$63 \mathrm{Al}$ decir de JAVIERRE "la solemne ceremonia le suavizaría las tristezas vividas" en Historia de las diócesis, 405. Sin duda fue un abrazo de esperanza para el corazón del pastor en el doliente, sufrido y temerario 1932. 
validez ritual al haber sido realizada en una iglesia artísticamente fenecida ${ }^{64}$.

La respuesta vaticana llega casi un año después, el 24 de febrero 1932, autorizando la dedicación o consagración que debía ser realizada por el cardenal en persona según el ritual y tras adaptar la mesa de altar del retablo principal que debía ser consagrado siguiendo fielmente las disposiciones de las rúbricas. El escrito valida así el argumento cardenalicio por lo que la autoridad vaticana, ante la inexistencia de documentación que la demostrara, coincidía y oficializaba el pensamiento de Ilundain, revalidando así que la nueva Catedral de Sevilla no había sido dedicada hasta ese momento. ${ }^{65}$

Ante esta notificación de la Congregación de Ritos, surgen las dudas referente a porqué tenía tanto interés Ilundain en la consagración de su catedral, quiénes habrían investigado la documentación disponible y acaso, la más importante, la extrañeza que causa que un edificio que había sido elevado a catedral en 1252 y renovado con una gran estructura en 1506, tras un siglo de obras para convertirse en majestuosa catedral, no se hubiese dedicado a Dios con una solemne celebración. ${ }^{66}$

El sentido devocional vivido desde su niñez y su preciada preparación histórico- litúrgica llevaron a Ilundain a considerar siempre la innata importancia de la catedral como sede del obispo y madre eclesial del territorio eclesiástico. Se extrañaría, sin duda, cuando al leer la esplendorosa biografía de la Magna Hispalensis comprobase que esta aún no hubiese sido dedicada. Al cardenal hispalense se le hacía extraño que la catedral imperial que logró la patriarcalidad de la venturosa evangelización americana, que la catedral tan presente en la epopeya inmaculadista, que la catedral del exuberante siglo de oro de muerte y de eternidad, que la catedral de mentalidad neoclásica o la romántica coloreada de turismo, la catedral de su episcopado, la de la exposición de 1929 y de su congreso mariano iberoamericano

64 El protocolario camino para la consagración está trazado en el texto del acta oficial de la ceremonia que recoge TOVAR: Ensayo biográfico,449-450.

65 Cf. el término de construcción de la catedral y un excelente estudio de su arquitectura en Alfonso Jiménez Martín, Anatomía de la Catedral de Sevilla. Sevilla, Diputación Provincial, 2013.

66 Cf. Eustaquio Ilundain Esteban, Carta para anunciar al clero y a los fieles encomendados la dedicación de la Catedral de Sevilla. Separata de BOAS, 13 de octubre de 1932. 
aún no estuviese consagrada. Incluso, era una exigencia para don Eustaquio de índole personal, pues todas las catedrales, menos una hasta esa época al no ser todavía diócesis, que habían formado parte de su trayectoria religiosa y de su misma vida sí lo estaban.

Así, la catedral de la ciudad que lo vio nacer y donde transcurrieron los años de la niñez, Pamplona dedicada, como la sevillana, al misterio de la Asunción de la Virgen fue construida entre los años 1394 al 1501 y levantada su fachada en el período que abarcan los años 1784 al 1805. Anualmente, se conmemora litúrgicamente el recuerdo de su dedicación cada 10 de abril ya que fue celebrada ese día de 1127, fecha que se ha impuesto a la convenida anteriormente de 1124, por medio del prelado oficiante y titular de la diócesis, Sancho de Larrosa (1122-1142), que la data por un testimonio epistolar fechado tres años después. ${ }^{67}$

Ciudad Real y Segovia tuvieron a Ilundain como canónigo, en la primera como magistral y en la segunda como arcipreste. El origen de la catedral manchega se encuentra en la devoción a la Virgen del Prado, para quien Alfonso x el Sabio mandó se realizase un santuario que con el transcurrir de los años sería declarado templo prioral por el beato Pío Ix en 1875 y obispado de las cuatro órdenes militares, creándose en el mismo monumento el obispado de Ciudad Real. La dedicación se alargó en el tiempo, hasta el 26 de mayo de 1967 celebrada por el prelado titular Juan Hervás y Benet (1955-1976), dos años después que san Pablo vi dedicase como basílica menor el templo prioral. ${ }^{68}$ Por su parte, la seo de Segovia, dedicada también al misterio de la Asunción, artísticamente representa un gótico muy tardío al estar fabricada en el siglo XVI, fue dedicada el 16 de julio de 1768, como se aprecia también de manera tardía, bajo el pontificado de Juan José Martínez Escalzo (1765-1773). ${ }^{69}$

El primer obispado de Ilundain, el único anterior a Sevilla, tiene su sede en la catedral de Orense dedicada a San Martín, edificada entre las centurias XII y XIII, siendo basílica menor por decisión del beato Pío Ix en 1867. Fue consagrada en el año 1118, siendo el obispo titular

67 Cf. Autores Varios, La catedral de Pamplona. Dos tomos. Pamplona, Caja Rural de Pamplona, 1994.

68 Cf. Hermenegildo Gómez Moreno, Ciudad Real monumental: Catedral basílica, San Pedro, Santiago. Sevilla, Ediciones Gever, 1985.

69 Cf. José Antonio Ruiz Hernando, Las trazas de la Catedral de Segovia. Segovia, Diputación provincial, 2003. 
Diego III (1100-1132) y el consagrante Mauricio Burdino (1109-1118) arzobispo de Braga. Su recuerdo litúrgico se celebra el 23 de junio, en la víspera de la solemnidad de la natividad de Juan el Bautista. ${ }^{70}$

Aunque hasta el momento que escribo estas líneas el silencio documental no lo corrobore tengo firme convicción que fue el propio Ilundain el que personalmente planteó la historia y la dedicación de la catedral sevillana, silencio que persiste para fijar los nombres de los investigadores que, destinados por Su Eminencia para tal fin, no encontraron confirmación de la celebración dedicatoria referente al nuevo edificio. Tengo para mí que dos hombres que auxiliarían la búsqueda del prelado son los de Laureano Tovar, su familiar, y el capellán de San Fernando, José Sebastián y Bandarán, que ya poseía peso específico en el clero hispalense, el mundo académico y la sociedad sevillana.

Laureano Tovar conoció a Ilundain siendo alumno del seminario de Segovia donde el futuro cardenal de Sevilla daba clases y era rector desde 1903, hasta su consagración al año siguiente como obispo de Orense. El joven seminarista siguió a don Eustaquio hasta su sede gallega como familiar, cargo que mantendría con el traslado del prelado a Sevilla y hasta su muerte en 1937, siendo nombrado por el arzobispo como canónigo de la catedral andaluza el 21 de marzo de $1922 .{ }^{71}$ Gracias a él, conocemos mucho del cardenal navarro gracias a la extensa y prolija biografía que le dedicó, siendo también muy interesante un estudio que realizó sobre el significado artístico y religioso de la catedral de Orense, ${ }^{72}$ publicando hasta 1951 muchos libros de temática religiosa. ${ }^{73}$ Murió en Sevilla el 24 de julio de 1953. ${ }^{74}$

José Sebastián y Bandarán dicta mediante su vida el desarrollo del siglo XX en la religiosidad y vida sevillana hasta su fallecimiento en 1972. Había nacido en la feligresía de la Magdalena en 1885, presbítero en 1909 en la iglesia de los jesuitas donde cantó la

70 Cf. Miguel Ángel González García, "Catedral de Ourense”, en Ramón IzQuierdo PERRín (ed.), Las catedrales de Galicia. León, Ediciones Leonesas, 2000.

71 Cf. ACS, Secretaría, Personal, Libro 282, Libro de entrada de los Señores Prebendados (1698-en uso), F.27vto.

72 Cf. Laureano Tovar GonzÁlezz, Simbología de la Catedral de Orense. Orense, 1919.

73 La última obra que conozco de su pluma está escrita a petición del Cardenal Segura en torno al Año Santo de 1950 en seis tomos y con el título: Luz de la fe. El último vio la luz en 1951.

74 Cf. ACS, Secretaría, Personal, Libro 382, F.27vto. 
primera misa y en cuya residencia auxilió un año después los últimos momentos del infatigable misionero con fama de santo Padre Tarín. Nombrado capellán real en 1920, se le acumularon los honores: predicador oficial, académico de Buenas Letras, cofrade meritorio, sevillano ejemplar y un largo etcétera. La relación con Ilundain fue buena, y eso que había tenido incluso una pena canónica en relación con los capellanes reales por una limpieza del rostro de la Virgen de los Reyes que don José encargó, sin consultar y por su cuenta y riesgo, al escultor José Ordóñez. ${ }^{75}$ Que estaría inmerso en la investigación y preparación de la dedicación de la catedral parece confirmarlo que el boletín oficial del arzobispado le encargase la crónica narrativa del histórico acto en octubre de 1932. Alcanzó el nombramiento de canónigo catedralicio el 7 de diciembre de 1955, entregando su alma en su casa del barrio de Santa Cruz el 21 de noviembre de 1972. ${ }^{76}$

En la actualidad, como también se preguntarían en 1931 y 1932, la duda de respuesta más importante es si la catedral de Sevilla aún no estaba en verdad consagrada en cualquiera de sus maneras arquitectónicas desde la reconquista de 1248. Debemos dedicar unas palabras al importante dilema.

La gran idea de san Fernando en su campaña reconquistadora es la obtención de Sevilla, y para ello llama junto a él a su hijo Alfonso, batallador en tierras murcianas, para el asedio hispalense. Cuenta la vieja tradición que el santo Rey elige para su triunfo incontestable el día 23 de noviembre, memoria litúrgica del papa san Clemente, pontífice mártir de finales del siglo I y llamado Padre apostólico por haber sido enunciador directo de las palabras recibidas de los apóstoles, pero Fernando también eligió la jornada por ser el veintiún aniversario del natalicio de su hijo Alfonso que recibiría la victoria de las huestes de Cristo como el mejor de los regalos. ${ }^{77}$

75 Una más amplia biografía del famoso sacerdote en José GÁmez Martín: "La Inmaculada Bandarán. Una Purísima Concepción de Francisco de Zurbarán y el capellán real hispalense José Sebastián y Bandarán", en coord. por Felipe Lorenzana de la Puente - Félix IÑesta Mena - Francisco J. Mateos Ascacíbar (eds.), La representación popular: historia, problemática actual y otros estudios sobre Extremadura. Badajoz, Sociedad Extremeña de la Historia, 2013, 411-414.

76 Cf. ACS, Secretaría, Personal, Libro 382, F.47vto.

77 En este año en el que se conmemora el VIII centenario del nacimiento del rey Alfonso es de obligada lectura la completa biografía que le dedicó el catedrático de la universidad hispalense Manuel GonzÁLEZ Jiménez, Alfonso x el Sabio. Madrid, Ariel, 2004. 
La entrada oficial se lleva a cabo en otro día de fasto litúrgico, el 22 de diciembre, memoria de la traslación de los restos de san Isidoro a León para salvarlos de la amenaza enemiga en 1063.

La procesión de entrada laureó la magnificencia de la devoción real, con la familia en pleno, los nobles, los obispos, el clero, las órdenes religiosas y todos los caballeros que habían logrado la victoria. Al llegar el cortejo a las puertas del Arenal, el rey moro le entregó las llaves de la ciudad como símbolo elocuente de la sumisión total.

Tras el desfile triunfal, la imagen mariana más venerada por el rey santo, la actual Nuestra Señora de los Reyes Patrona de la Ciudad, presidió el altar mayor de la mezquita aljama que en la víspera había sido purificada por Don Gutierre, obispo de Córdoba y a la sazón electo para Toledo. Hablamos como dicen las crónicas de una bendición purificadora, muy lejana por lo tanto de la suntuosidad de la dedicación. ${ }^{78}$

La familia real toma como gran alabanza a Dios la purificación de la mezquita cuyo titular será el misterio mariano de la Asunción y Fernando con el interés de oficializar el cuerpo del nuevo territorio religioso, erige veinticuatro nuevas parroquias distribuidas por el centro urbano. No causa extrañeza pensar que el propio Rey Santo fundara el cuerpo de canónigos para la responsabilidad de la organización catedralicia, llegando incluso a afirmar los cronistas el deseo fernandino de que la Iglesia de Sevilla superara a la de Toledo, Sede Primada de España.

Sin embargo, queda constancia documental que Fernando otorgó la primera dotación económica para el nacido cabildo capitular casi cuatro años después de la reconquista, el 20 de marzo de $1252^{79}$ debido a su deseo de conseguir la sede arzobispal hispalense para su hijo Felipe que ya había sido elegido en el deseo real como nuevo prelado de la instaurada sede sevillana. El 24 de junio de 1251 el papa Inocencio IV (1243-1254) ya señala a don Felipe como "electo" en bula dirigida a los componentes catedralicios en la que concede numerosas indulgencias a los fieles que estuviesen presentes en la dedicación de la catedral que según el documento pontificio se estaba preparando y que nunca debía ser celebrada por Felipe pues no

78 Un relato lírico sobre la entrada es el de Carlos Ros en Sevilla día a día. Sevilla, Manos Unidas, 1996, 627-628.

79 Cf. AAS, Sección IX, Fondo Histórico General, Caja 4, documento 35. 
había recibido la consagración episcopal, seguramente por sus propias dudas sobre la vocación religiosa, dudas que siguió plateándose hasta la separación del estado clerical. Por la buena relación papal con Alfonso x y el deseo real de la búsqueda de todo el boato y decoro para la sede hispalense, otra bula papal de Inocencio el 23 de agosto de 1254 le permitía usar la mitra y el anillo aún sin haber sido consagrado como sucesor de los apóstoles. ${ }^{80}$ En bula de Inocencio IV de 1252, se concede indulgencia para los fieles que visitasen el templo en el aniversario de la dedicación que además — sostiene el documento pontificio - sería el 11 de marzo, lo que nos indica que la ceremonia debió celebrarse ese día con toda rotundidad, poco antes de las primeras dotaciones al cabildo del reinado fernandino. ${ }^{81}$ Esta fecha consagratoria, documentada fehacientemente, es la que siempre fue aceptada para el aniversario o dedicación de la catedral que se celebra cada 11 de marzo en la archidiócesis desde tiempo inmemorial, es decir, desde tiempo medieval, lo que consolida que no se hubiese realizado una dedicación a partir de 1506 ya que esta última es la que debería celebrarse tras la de 1252 sobre la bendecida mezquita. Actualmente se la sigue recordando, con la consideración de fiesta, según contemplan Las Misas de los Santos Propios del Arzobispado de Sevilla, aprobadas por la Sagrada Congregación para los Sacramentos y el Culto Divino. ${ }^{82}$ En la redacción y calendario de estas celebraciones locales para adaptarlas a la reforma posconciliar tuvo puesto importante don Miguel Artillo, prefecto de liturgia de la catedral, que con aquella generación de distinguidos calonges: Gil Delgado, Juan Guillén, Juan Garrido, Juan Ordoñez... que buscaron lo mejor para la iglesia hispalense en el difícil y politizado pontificado posconciliar del cardenal Bueno Monreal. ${ }^{83}$

Esta dedicación medieval era más que necesaria en su contexto de solemnidad, pues tras la muerte de san Fernando en auténtico olor de santidad el 30 de mayo de 1252, su hijo Alfonso hereda el

80 Cf. los inestables años del infante Felipe en la sede de San Isidoro en José Alonso Morgado, Prelados sevillanos o Episcopologio de la Santa Metropolitana y Patriarcal Iglesia de Sevilla. Sevilla, 1906, 243-249.

81 Cf. ACS, Sección IX. Fondo Histórico General. Caja 145, documento 23.

82 Cf. Misas de los Santos Propios del Arzobispado de Sevilla. Sevilla, Arzobispado de Sevilla, 1980.

83 Cf. Julio Jiménez Blasco, El Cardenal José María Bueno Monreal, Un humanista integra, Una biografía (1904-1987). Sevilla, Universidad de Sevilla y BAC, 2016. 
deseo de su padre y concede al cabildo grandes reales privilegios como igualar en los mismos a la iglesia sevillana a la de Toledo, ${ }^{84}$ conseguir de los pontífices gracias e indulgencias en la memoria de su padre ${ }^{85} \mathrm{y}$ fundar una procesión con el fin de sacralizar el aniversario de la reconquista. ${ }^{86} \mathrm{Al}$ citar estos beneficios de Alfonso, parece obvio que todas las gracias otorgadas, algunas de indudable sintaxis litúrgica como la procesión de la espada del 23 de noviembre, no podían o no debían más bien ser concedidas a una iglesia no consagrada a Dios, fortaleciendo además de dicha manera la fecha del 11 de marzo de 1252 como la de la celebración de dedicación de la iglesia catedral de Sevilla. Sin discusión a este respecto, claramente Ilundain se refería al estreno quinientista del nuevo edificio, como el mismo confirmaría, que no había sido dedicado aún y a la necesaria ejecución de una mesa de altar para el retablo mayor adaptada a las rúbricas emanadas de la Santa Sede.

La mesa de altar que se encontraba bajo el retablo mayor carecía de todo mérito artístico, formando por tres cuerpos sin armonía en la parte superior, con un color tierra perfilado tanto por calidad como cromatismo, desentonando por su pobre léxico formal con la magnificencia del altar. Ilundain comprendió la necesidad del encargo y pensó que el arquitecto válido para su dibujo de alzado era Vicente Traver y Tomás. El propio cardenal en la entrevista con Pío XI en el desarrollo de la visita ad limina le habló al Santo Padre de construcciones artísticas que estaba realizando en su labor ministerial, el inteligente y valiente papa Ratti mostraría complacencia por lo realizado y con curiosidad preguntó la tipología del altar de la capilla mayor. Ilundain a su vuelta a la sede se lo envió a vuelta de correo cuando Traver se lo entregó a primeros de septiembre, asombra que fuese aprobado a los pocos días y más el que la mesa estuviese y el 2 de octubre, por lo tanto, con anticipación suficiente para la celebración. ${ }^{87}$

La elección de Traver para el diseño del altar parece más que justificada pues el año anterior ideó los planos para la iglesia de la Concepción en Nervión que al final no pudo concluirse en la hechura

\footnotetext{
Cf. ACS, Sección IX. Fondo Histórico General. Caja 118, documento 1-7.

Cf. ACS, Sección VII. Varios. San Fernando, Caja 33, documento 3.

Cf. ACS, Sección IX. Fondo Histórico General. Caja 58, documento 31.

7 Cf. Rocío Luna Fernández Aramburu - Concepción Serrano Barberán, Planos y dibujos de la Catedra de Sevilla (siglos XVI-XX). Ilustrado con planos, dibujos y detalles de la Catedral. Sevilla, Diputación Provincial, 1986, 85.
} 
al completo, iglesia que sería consagrada por Ilundain en 1931. El arzobispo puede ser que validara ya el trabajo del arquitecto tras la construcción en 1929 de la casa de las adoratrices.

Traver nació en Castellón en 1888 y con su venida a Sevilla y el apoyo de instituciones de prestigio, como el Ateneo, logró el importante puesto de arquitecto director de la exposición iberoamericana tras la dimisión del renombrado Aníbal González, realizando importantes obras como el actual teatro Lope de Vega donde se encontraba el pabellón de Sevilla. Precisamente el diseño de nuestro altar y una intervención en la casa de los Mañara son sus últimos trabajos en Sevilla, pues volvió a su ciudad en 1933 donde seguiría con su labor, siendo nombrado arquitecto diocesano de la archidiócesis de Valencia en julio de 1939 por el arzobispo Prudencio Melo y Alcalde (1923-1945). Traver yTomás falleció en 1966 en la tierra que lo vio nacer. ${ }^{88}$

Buen acierto de nuestro arquitecto fue separar la mesa del retablo que fue construida con mármol de Almería en la base y de Carrara en la tapa a la que se le añadió unas gradas para la colocación de enseres litúrgicos fácilmente desmontables. La tapa sobresalía por su peso, cercano a las tres toneladas, por lo que fue colocada por una polea y sus medidas alcanzaban los cinco metros y medio de largo, casi siete de ancho y 0,25 de grosor. Se cuidó la unión de la tapa con la superficie completa de la mesa con una capa de cemento, sin aparición de elementos que alterasen el nudo de factura de la obra.

El frontal delantero de la mesa de altar se divide en tres cuerpos, separados a su vez por cuatro juegos de columnas pareadas de inspiración jónica que sirven de base, en el cuerpo central aparece una cruz griega con el alfa y la omega ${ }^{89}$ La tapa tenía realizada en su centralidad el sarcófago para la colocación de las reliquias martiriales. El efecto de la obra es resultante, con ribetes de goticismo tardío de tal que según confesiones del propio Pío XI, recogidas por

\footnotetext{
88 El historiador José Carlos Pérez Morales se doctoró en 2016 con la tesis: El arquitecto Vicente Traver y Tomás (1888-1966) <https://idus.us.es/handle/11441/40255> [consulta: 14 septiembre 2021]. Anteriormente, cf. IDEM, Vicente Traver Tomás. Un arquitecto entre Sevilla y Castellón. Castellón, Diputación y Universidad Jaume I, 2011.

89 Las descripciones de la obra son escasas pero las medidas del conjunto. Las encontré en HMS, Diario El Correo de Andalucía. Sevilla, 21 de octubre de 1932. Por las precisiones la crónica de la consagración de la catedral, aún sin llevar firma, es obra evidente de Bandarán (así era llamado por el pueblo sevillano).
} 
el biógrafo del cardenal y algunas crónicas de prensa, era digno de cualquier basílica romana. ${ }^{90}$

La empresa que llevó a cabo el proyecto fue la Sociedad anónima de construcciones de Sevilla que ya había colaborado anteriormente con Ilundain y Traver y que representa en sí misma la aparición de la empresa hispalense desde el último tercio del xIx y su casi lograda y soñada plenitud con el horizonte celebrativo de la exposición universal. ${ }^{91}$

$\mathrm{Al}$ consultar las diferentes fuentes que sirviesen para la descripción de la ceremonia de la dedicación catedralicia en la Sevilla de 1932, ante todo, me sorprendió el laconismo informativo de las actas capitulares del año, sobre la que debía ser importante celebración litúrgica, que al decir del propio Vaticano no se había celebrado desde la Sevilla de inicios del siglo xvi y máxime si tenemos en cuenta lo abundante que son estas actas de sesión para el estudio de otro tipo de celebraciones. El día 6 de abril, los canónigos reciben aviso escrito del Cardenal en el que anuncia que la Congregación de Ritos ha autorizado la consagración del templo por lo que los capitulares nombran una comisión formada por el presidente, prefecto de ceremonias, mayordomo y secretario con el fin de disponerse a una entregada colaboración con los deseos cardenalicios. ${ }^{92}$ Tras esto, solo queda constancia de una nueva misiva enviada por el Cardenal a los canónigos el 18 de octubre, dos días antes del jueves 20, día en que iba a realizarse la dedicación texto que también fue enviada a los párrocos y religiosos. En palabras de Ilundain:"el próximo jueves 20 de octubre con el favor de Dios procederemos a consagrar solemnemente Nuestro Santo Templo Catedral y el nuevo altar fijo instalado en la capilla mayor o presbiterio del mismo templo". Su Eminencia pide rezos para la empresa y decreta una octava de celebración por la dedicación, a solemnizar en todas las iglesias sevillanas. ${ }^{93}$

El miércoles 25 de octubre, el secretario lee en cabildo una emotiva carta dirigida por Su Eminencia en la que da efusivas gracias por

90 Tovar, Ensayo biográfico, 432-433, recoge el testimonio de Pío XI al pie de una fotografía de la mesa ya colocada en el altar mayor; acompaña también otro testimonio de la antigua y pobrísima mesa que había llamado la atención del Cardenal por su arcaica hechura.

91 Cf. José Almuedo Palma, Ciudad e industria: Sevilla ,1850-1930. Sevilla, Diputación Provincial, 1996.

92 Cf. ACS, Autos, Libro 234 (1931-1938), F.53vto.

93 Cf. Ibidem, F.67. 
la solemnidad de la consagración como ya había manifestado personalmente al deán y secretario que lo habían felicitado personalmente al día siguiente de la ceremonia comisionados por el cabildo para tal fin. Ilundain manda que el acta oficial de la celebración sea custodiada en el archivo y se haga una copia de la misma para que conste en el escrito que recoja las noticias de la presente reunión capitular, finalmente el purpurado declara:

Sobre lo que hace a la celebración litúrgica del aniversario de esta consagración, mientras no disponga otra cosa la Santa Sede, se celebrará el mismo que viene celebrándose, el aniversario de la antigua Catedral que es el día 11 de marzo, cuyo templo, como usted no ignora fue derribado en el siglo XV para ser edificada la actual iglesia Catedral, suntuosa, magnífica y más suntuosa que aquella. ${ }^{94}$

El Cardenal dejaba claro que la consagración era para el nuevo edificio del siglo XVI, en el que no se había celebrado la ceremonia dedicatoria hasta entonces, como ya vimos la fecha del 11 de marzo perduraría hasta nuestros días con claro juicio de la Santa Sede a favor de conmemorar la epopeya de la reconquista de la nueva arquitectura catedralicia. Antes de dar por finalizada la sesión el deán informó que el señor Traver"manda mención extraordinaria, con planos y dibujos, de la obra de reforma llevada a componer la mesa del altar mayor", la misma será dejada unos días en la secretaría para consultas de los calonges interesados antes de ser llevada al archivo general. ${ }^{95}$

El lector entenderá mi sorpresa al encontrar ese frío enunciado, como para solventar un trámite, en los escritos canonicales lo que puede hacer aventurar si los capitulares estaban satisfechos por el deseo del cardenal o mostraban algún tipo de reticencia, reticencia que conociendo el sentir sevillano en la demostración perenne de su arcaico origen, esta puede estar relacionada con la mirada de algunos que podrían considerar un desdoro histórico para la catedral que una liturgia, propia de sus primeros tiempos, se llevase a cabo a comienzo de la tercera década del siglo XX. Nos movemos solo en terreno

94 Ibidem, la carta del Cardenal en los folios 74-75 y la copia textual del acta en los 75vto-77vto. La escasa mención a la ceremonia marida con la extrañeza que causa al estudiar durante años el archivo capitular, que años tan trascendentales para la historia de España como los de 1931 a 1938 aparezcan en un solo libro, el 234 y el último que por ley de fechas puede ser consultado.

95 Ibidem, F.78. 
de suposiciones, aunque a decir verdad lo vertiginoso de la época, tampoco hacía muy factible ni asumible una posición de defensa histórica cuando las iglesias de la provincia eran pasto de las llamas de octubre de 1932, en ese otoño seco y poco lluvioso en el que se coloca por primera vez la bandera de Andalucía junto a la de España en los balcones oficiales, lo que parecía validar el sentimiento autonómico. ${ }^{96}$

$\mathrm{Al}$ estudiar la prensa del año en Sevilla se parte como premisa que todos los periódicos eran esclavos de tendencias políticas o escribían al interés de opciones particulares o determinados intereses, así La Unión y El Noticiero Sevillano eran patronales, $A B C$ monárquico, El Correo de Andalucía católico y El Liberal con algo más de apertura en la significación política, pero sin ser tampoco vocero del nuevo régimen. ${ }^{97} \mathrm{El}$ acceso a las informaciones hemerográficas de la municipal de Sevilla tampoco resultó satisfactorio, tan solo mencionan la dedicación $A B C$ y El Correo de Andalucía que le dedica dos columnas el día 21 bajo el titular "Ayer mañana fue consagrada la Catedral"y un resumen de la ceremonia sin firma que como ya indiqué en anterior nota a pie de página es atribuible por razones estilísticas a Sebastián y Bandarán, que como era habitual en él ofrece unas notas de carácter histórico sobre el sentido de la dedicación a lo largo de la historia.

El Boletín Oficial de la Archidiócesis sí recoge una amplia crónica del mismo Sebastián y Bandarán que es, sin duda por su exacta meticulosidad, la mejor información que poseemos del desarrollo de la ceremonia. Se trata de una crónica escrita con brío y alegría, que con detalles más precisos y periodísticos explica lo vivido de manera protocolaria que recogería también pero más brevemente y con un lenguaje más ceremonioso el acta oficial de la misma. ${ }^{98} \mathrm{~A}$ don José Sebastián se le percibe la alegría como católico y sevillano que está presente en la dedicación del templo y sin entrar en disquisiciones sobre la posibilidad de haberse podido celebrar un acto de consagración en tiempos medievales.

96 Cf. Marcos Ramos Romero, "Una bandera para Andalucía", en XI Congreso Internacional de Vexilología. Madrid, Sociedad Española de Vexilología, 1987, 103-156.

97 Cf. María Victoria Fernández LuceÑo, "La política en Sevilla en la segunda república”, en Juan Ortíz Villalba (cord.), La Segunda República en Sevilla. Sevilla, Ayuntamiento y Patronato del Real Alcázar, 2004, 39.

98 Ambas fueron transcritas con dadivoso acierto en Tovar, Ensayo biográfico, 445-450. 
En el canto de vísperas de la tarde del 19 de octubre el cardenal arzobispo de Sevilla desde su residencia marchó a la Santa Iglesia Catedral para venerar las reliquias de los santos mártires que iban a ser colocadas en el centro de la nueva mesa de altar mayor, siguiendo lo dispuesto en rúbricas. En una urna catedralicia de interés barroco el prelado colocó la cajita con las reliquias, junto a tres gramos de incienso que debían ser quemados al día siguiente en la nueva mesa que se debía consagrar. El cabildo decidió instalar en la sala de la contaduría un oratorio donde se daría escolta a las reliquias hasta su traslado procesional al altar mayor durante la ceremonia de la mañana siguiente. Las reliquias eran de primera categoría, es decir, un trozo de hueso, enviados por la Sagrada Congregación de Ritos y refrendados con su auténtica, las cuales pertenecían a santos mártires de la persecución cuyos cuerpos descansaban en las catacumbas romanas: Macario, Vicente y Felicísima. De los tres bienaventurados, la más conocida era santa Felicísima, pues tanto Vicente y Macario tenían compañeros del santoral de igual nombre de mayor fama entre los fieles como san Macario de Egipto o de Alejandría (300-390) y san Vicente Mártir, patrón de Valencia (murió en 304). Santa Felicísima fue una joven ciega que san Graciliano convirtió a la verdadera fe e intercedió ante Dios para que recobrase la visión. Ambos, maestro y discípula, fueron ejecutados por decapitación en Faleria, durante la persecución de Diocleciano en 303. ${ }^{99}$

Aunque era obligatorio recordarlos en cada altar de la iglesia católica donde se celebrara la Eucaristía con la presencia de su recuerdo óseo, la devoción a los mártires romanos había retomado un nuevo cauce devocional durante todo el siglo XIX, potenciado por el pontificado del beato Pío IX, así como por la prosperidad del turismo internacional que llevó a la Ciudad Eterna a un inexcusable lugar en la nueva manera de entender el viaje.

La mañana del 20 de octubre amaneció con sol radiante, pero con temperatura suave que anunciaba la llegada del imperante otoño que en Sevilla se hace tardío por la duración veraniega, tras el canto de las horas matutinas, una comisión del cabildo catedral se desplazó al palacio arzobispal a recoger al titular, don Eustaquio los esperaba

99 La persecución a los cristianos de los primeros siglos hasta ahora en el excelente estudio de Paul A. Marshall - Lela Gilbert - Nina Shea (eds.), Persecuted: The Global Assault of Christians. Londres, Nelson, 2018. 
en el salón del Trono, revestido con bella capa pluvial con elementos marianos, dirigiéndole unas palabras de bienvenida. Precedido por la cruz catedralicia y la comisión canonical, marchó hacia la catedral en la que entró por la Puerta de los Palos, donde lo recibió el cabildo en pleno. Esta costumbre de esperar al arzobispo en la puerta del pie de la Giralda pervive hoy e incluso dos veces al año en la Pascua de Resurrección y la Purísima el cabildo en pleno lo recoge en palacio, costumbre originada en la segunda mitad del siglo XVIII. ${ }^{100}$

El encargado de la dirección ceremonial fue el prefecto don Antonio Pabón, auxiliado por el beneficiado don Marcos Mir. Correspondió el honor de acompañar a Su Eminencia, como diáconos de honor a los capitulares Balbino Santos Olvera que poseía el oficio de lectoral y a don Francisco Martín Robayo. Ante las reliquias el Cardenal oró, cantándose los salmos del día. Seguidamente, el ceremoniero mayor o prefecto organizó la procesión precedida de la cruz patriarcal catedralicia y formada por los componentes de ambos cabildos, catedral y capellanes reales, el Schola Cantorum del seminario y el séquito litúrgico de Su Eminencia. Salió la formada procesión por la Puerta de san Miguel que se cerró seguidamente y se dirigió a la vecina Puerta Mayor que también se encontraba cerrada, como todas las catedralicias, en donde de rodillas el Cardenal entonó el canto de la letanía de los santos y bendijo el agua y la sal, todo el cortejo procesional rodeó el largo perímetro de la catedral exteriormente y desde la derecha, en dirección al Sagrario para que Cardenal Arzobispo asperjara tres veces todos los muros en tres movimientos, en la parte superior, inferior y media.

Llegados de nuevo a la Puerta Mayor, Ilundain bendijo tres veces con el asperje, momentos antes de golpearla con el báculo para que fuese abierta por el diácono que revestido con preciosa dalmática blanca del tesoro catedral era la única persona que se encontraba dentro de la misma.

Entraron todos los componentes de la procesión. Parados a la mitad del crucero, se cantó el Veni Creator y comenzó el rito bendicional en el interior sacro, con tres signos de bendición cardenalicios dirigidos al altar mayor, la nueva mesa y a todo el espacio catedralicio. Durante el canto, los acólitos esparcieron la ceniza sobre el suelo,

100 Cf. ACS, Sección III, Liturgia, Libro 75, Libro Diario de la Diputación de Ceremonias, 1763-1769. 
alcanzando una forma de cruz entre las puertas de Campanillas, los Palos, San Miguel y Baptisterio cruzándose los brazos en el centro del crucero. Con el báculo, Ilundain dibujó sobre ella todo el alfabeto en griego y latín, mientras el coro cantaba el Benedictus. Subido al altar mayor, el prelado bendijo agua, sal y vino por separado, para después mezclarlos, dictó palabras sobre el poder del agua salvífica y marchó nuevamente la comitiva a la Puerta Mayor, sus hojas interiores fueron signadas arriba y abajo con el báculo para marchar seguidamente al altar mayor para comenzar la segunda parte de la ceremonia o consagración de la mesa de altar.

Con el agua bendita y mezclada, don Eustaquio ungió el altar con cinco cruces en el centro, y otras cinco en cada lateral; y, a la conclusión, con el hisopo de hierba, asperjó todo el perímetro del altar, rodeándolo siete veces. Se formó de nuevo la procesión desde allí para la bendición de todos los muros, capillas y altares y el Sagrario, como el Cardenal hiciera con los exteriores lo realizó con tres movimientos y el uso del asperje natural. En esta extensa y dilatada parte ceremonial, es sabida la amplitud de la catedral. El coro entonó el salmo Miserere y otros cantos y plegarias de tipo penitencial.

Roció el pavimento con el agua formando una gran cruz que abarcara la extensión de la basílica, bendiciéndola tres veces en cada uno de los puntos cardinales, mientras se deprecaba al cielo con una plegaria, pidiéndole a Dios Padre su protección para el arzobispo, clero, templo y fieles. El Cardenal subió al altar y bendijo y roció con el agua gregoriana la hondonada hecha en la mesa, que con forma de sarcófago iba a recibir las reliquias de los santos mártires romanos que habían sido glorificados con la palma del martirio.

En ese momento, se abrieron las puertas de acceso del templo para la entrada de los fieles que ya podían participar en el traslado de las reliquias al altar, una vez celebrados los ritos anteriores que el ceremonial consideraba secretos, por lo que solo podían formar parte el arzobispo junto a su clero y auxiliares litúrgicos.

Las reliquias fueron portadas en andas adornadas con flores rojas, llevadas a hombros por cuatro beneficiados que vestían con vestiduras sacerdotales del color martirial y eran los señores: Ansó, Díaz Arnosa, Moreno Melendo y Muñoz Torrado. El cardenal con su séquito se dirigió a la Puerta Mayor por la que entraron las reliquias que habian salido a la calle por la vecina Puerta de San Miguel. Tras rociarlas con el agua e incensarlas, don Eustaquio pronunció unas emocionadas 
palabras en las que refería la importancia de la celebración para la iglesia de Sevilla, describía la gloriosa historia de la iglesia hispalense, definía el día como uno de los más importantes de su vida ministerial, elogiaba la obra salvífica de Cristo Resucitado y culminaba, como hizo durante todo su pontificado y su vida, con unas preciosa lírica dedicada a la Virgen y su relación con el misterio de Cristo y de la Iglesia, glosa que parecía anteceder el capítulo VIII de la Lumen Gentium o la Marialis Cultus de san Pablo vi. A la conclusión, ungió dos cruces que se encontraban en las puertas y entró de nuevo el cortejo en interior, seguido de los fieles. La participación numérica de estos fieles no está recogida en las crónicas, aunque teniendo en cuenta la situación que se vivía, el poco realce dado a la ceremonia que se extendería a la bibliografía posterior y a que era un jueves laborable, su concurso asistencial debió ser limitado teniendo en cuenta la importancia histórica de la catedralicia celebración.

Cuando la parihuela llegó al altar, Ilundain ungió el sarcófago de la mesa en sus cuatro ángulos, también colocó el crisma en los mismos espacios interiores de la tapa de mármol que lo cubría. Vicente Traver subió al presbiterio y fijó el lugar con el cemento que le suministraron dos auxiliares.

Bendecido el incienso, perfumó el prelado primeramente el lugar que acababa de cerrarse, y rodeó el altar, incensándolo, tres veces. Tras el suave olor, el Cardenal ungió el altar en el centro y las esquinas con el óleo de los catecúmenos, lo volvió a incensar al completo y nuevamente usó el óleo en los mismos lugares, culminando con un rodeo del altar con el incensario comenzando esta vez desde el lado izquierdo. Ungió la mesa con el Santo Crisma cinco veces y la volvió a incensar. Se derrama todo el contenido de las ampollas del óleo y el crisma desde el lado izquierdo y hacia al centro para terminar en el derecho, con la mano derecha, librada de anillo, el Cardenal los mezcla para bañar toda la superficie al completo. Durante todos estos ritos se cantaron diversos salmos e himnos pascuales.

Bajado del altar, Ilundain comienza a consagrar las doce cruces rojas que se habían colocado pintadas en los muros catedralicios, representando a los doce apóstoles o las doce tribus de Israel, iluminadas cada una de ellas por cirios colocados en soporte de hierro. El Cardenal llegaba a cada cruz y subía a una escalera, ideada y construida por los carpinteros catedralicios para la ocasión, y desde la plataforma ungía cada una de las cruces. Es fácil entender el esfuerzo 
físico que el Cardenal debió sufrir al subir y bajar las escaleras, no olvidemos que Ilundain era un hombre de setenta años que había sufrido ya y desde joven algunas enfermedades serias.

La larguísima ceremonia continuó en el altar mayor donde el prelado colocó gramos de incienso sobre la mesa tras incensarlo, sobre el motón de perfume colocó unas velitas que se iban consumiendo mientras el coro entonaba una antífona a Dios Creador, en seguida don Eustaquio, con su voz grave y solemne, entonó un prefacio, mientras bendecía el altar siete veces. Una vez terminada la oración bendijo la cruz de mármol con los siete candeleros que la iluminaban.

El señor Cardenal marchó a su trono sobre dosel colocado en el lado del evangelio donde bendijo los manteles que habían de ser colocados sobre el altar y desde donde se disponía a asistir a la primera misa que había de celebrase en la Catedral y en el nuevo altar dedicados.

La Misa fue celebrada por el capitular Severo Daza que poseía la dignidad de arcediano, siendo asistido como diáconos por los beneficiados Evaristo López y Antonio Herrera. En el momento de la comunión el número de fieles había aumentado ya que se acercaba el reloj a la una de la tarde. Al terminar la Eucaristía, el Cardenal dirigió unas palabras de agradecimiento antes de bendecir a todos. Asombró tanto la vivacidad litúrgica del Cardenal, que no me resisto a transcribir las palabras de Sebastián y Bandarán:

El Señor Cardenal consagrante no solo no dio muestra de cansancio ni fatiga, a pesar de lo diverso y penoso de algunas ceremonias, de la magna extensión de nuestra iglesia, del ayuno de la víspera, del peso de los ornamentos sagrados, sino que realizando con exquisita puntualidad todas y cada una de las prescripciones del Pontifical, nos edificó y admiró a cuantos tuvimos la dicha de admirar tan fausta consagración. ${ }^{101}$

Palabras que encierran la admiración de todos por la compostura y buen hacer del príncipe de la iglesia que llegó a la Catedral a las siete menos diez de la mañana y se retiró a sus aposentos a las dos y cuarto de la tarde, tras celebrar una ceremonia de intrincada complejidad física durante más de siete horas.

101 BOAS, 28 de octubre de 1932, núm. 1212, 277-283. La crónica de Bandarán culmina con una alabanza egregia a Ilundain y una entusiasta enhorabuena a todos los sevillanos, que como hemos visto, pasaron de puntillas sobre esta consagración. En su trabajo TOVAR, Ensayo biográfico, 445-448, reprodujo en su totalidad esta acertadísima y vivaz narración. 
La oficialidad de la ceremonia se cumplió con la firma del acta oficial de consagración que fue redactada por el propio Cardenal que la rubricó con su firma y escudo heráldico. Junto a la de Su Eminencia, aparecen las rúbricas de don Luciano Rivas como deán, don Jerónimo Armario, dignidad de tesorero y vicario general de la archidiócesis, don José Holgado Yusta, dignidad de capellán mayor de san Fernando, el secretario capitular y canónigo don Manuel Rodríguez y el notario eclesiástico del arzobispado don Antonio Herrera.

Por propia iniciativa del Cardenal, testimoniada también con su escudo, se colocó una lápida como recuerdo del hecho en el muro derecho exterior de la capilla mayor. El texto, de propia mano del prelado, redactaba el discurrir de la dedicación y la consagración del nuevo altar y anunciaba la indulgencia de cien días al fiel que visitase la Basílica en cada aniversario de la dedicación, indulgencias y gracias espirituales que comenzarían el próximo 11 de marzo de 1933. ${ }^{102}$

Tanto la placa recordatoria como las cruces consagradas están aún en los muros de la Magna Hispalensis como recuerdo parlante de la solemne ceremonia de 1932.

También por iniciativa del admirable prelado, Su Eminencia compuso la lección sexta en el oficio de las horas que debía ser cantado en el aniversario de la dedicación, añadido al que estaba en uso y autorizado, como correspondía, por la Sagrada Congregación de Ritos. ${ }^{103}$

La misma tarde de la celebración religiosa en los cuarteles sevillanos tenía lugar un acto ceremonia llamado "despedida del soldado" y en la que se homenajeaba a las tropas que se licenciaban o partían como personal al protectorado español. Contó con la presencia de autoridades, empeñadas también en dulcificar la relación de los mandos con el nuevo régimen político y fue recogida en gran parte de la prensa local, ${ }^{104}$ lo que hace más doloroso e injusto el silencio a la dedicación de la mayor Catedral de España.

$\mathrm{Al}$ día siguiente se produciría una noticia religiosa de carácter trágico que sí acapararía lugares importantes en la prensa local: el

102 El texto latino de la lápida conmemorativa es transcrito por TovAR, Ensayo biográfico, 450. Además, como dijimos en la nota 82 en el libro 284 de los autos capitulares del archivo catedralicio insertado entre los folios 72vto y 73.

103 También recoge el texto latino Tovar, Ensayo biográfico, 451.

104 Cf. HMS, El noticiero sevillano del 21 de octubre publica un amplio reportaje en página 3 con dos fotografías del acto. 
incendio intencionado de la parroquia de la Purísima Concepción de Gerena.

El siniestro comenzó entre las doce y media y la una de la madrugada al ser rociada con gasolina la puerta principal, prendiéndole una mecha, acción que fue vista por el mulero Antonio Ortiz, empleado de una casa propiedad del marqués de Albarraseda que quedaba frontera al edificio parroquial. Antonio avisó al sacerdote regente de la feligresía, José María Saldaña, al vecino Francisco Vega Jaime y a otros del pueblo que intentaron apagar el fuego, en lo posible, hasta la llegada de los bomberos. En la prensa del día 23 se da suculenta información de lo acaecido con fotografías de la iglesia herida y de los reporteros enviados a la cercana población entrevistado al sacerdote. El fino instinto periodístico, junto a alguna información policial, argumentaron la analogía del suceso con el también incendio de la parroquia de Aznalcázar acaecido el 7 de septiembre anterior. ${ }^{105}$ Las pérdidas de Gerena fueron cuantiosas, comenzando con el Sagrario y las Sagradas Formas que contenía, una imagen de la Purísima del siglo XVIII, otra del Corazón de Jesús, dos púlpitos, desprendimiento de las paredes y de la imagen de la Patrona de la localidad la Virgen de la Encarnación que se encontraba a la veneración de los fieles al pie del altar mayor. ${ }^{106}$

Ante tales sucesos que parecían seguir testimoniando el descrédito de las autoridades en el cuido a los edificios religiosos, el vicario general, mandado por Ilundain, visita a los pocos días, en Madrid el ministerio de justicia para levantar una queja de las inseguridades que el catolicismo vivía, inseguridades que desgraciadamente no solo eran en Sevilla. ${ }^{107}$ En esa visita está manifiesta la valiente actitud del cardenal Ilundain que ofrecía la mano para dialogar, pero al que no le temblaba el pulso para manifestar la queja y el dolor cuando los intereses de Dios y de sus hijos quedaban en entredicho.

\footnotetext{
105 Me parece el reportaje más completo el ofrecido por El Liberal del día 22 donde se realiza una extensa descripción del incendio con sus nefastas repercusiones en el interior y exterior de la iglesia. Para el incendio de Aznalcázar véase La Hormiga de Oro del 15 de septiembre del mismo año 1932. Ambos ejemplares en HMS.

106 Cf. José Hernández Díaz - Antonio SANCho Corbacho, Estudio de los edificios religiosos y objetos de culto de la ciudad de Sevilla, saqueados y destruidos por los marxistas. Sevilla, Junta Conservadora del Tesoro Artístico, 1936.

107 Cf. HMS, El Correo de Andalucía. 28 de octubre de 1932.
} 
El mes terminaría con una buena noticia para Su Eminencia, la terminación de la restauración de la iglesia parroquial de Santa Catalina en la que se había reforzado la techumbre y limpiado los retablos ${ }^{108}$ y el 1 de diciembre el prelado pasaba informe al cabildo sobre la terminación de la restauración de las vidrieras de la catedral, ${ }^{109}$ otro logro cardenalicio que nunca olvidó su ingente labor de mecenazgo artístico a pesar de lo inestable y doloroso de algunos de los años vividos a lo largo de su pontificado.

La consagración catedralicia de 1932 es un compromiso histórico para la liturgia de la catedral hispalense que estaba pendiente desde los primeros años del quinientos y quedó cumplido en la vertiginosa segunda república.

108 Cf. HMS, El Liberal. 30 de octubre de 1932.

109 Cf. ACS, Autos, Libro 234, F.87. 